Article

\title{
Selective Synthesis and Photoluminescence Study of Pyrazolopyridopyridazine Diones and $N$-Aminopyrazolopyrrolopyridine Diones
}

\author{
Ching-Chun Tseng ${ }^{1,2}$, Cheng-Yen Chung ${ }^{2}$, Shuo-En Tsai ${ }^{1,2}{ }^{,}$Hiroyuki Takayama ${ }^{3}$, \\ Naoto Uramaru ${ }^{4}$, Chin-Yu Lin ${ }^{5}$ (i) and Fung Fuh Wong $1,2, *$ (i)
}

1 The Ph.D. Program for Biotech Pharmaceutical Industry, China Medical University, No. 91, Hsueh-Shih Rd., Taichung 40402, Taiwan; u106308201@cmu.edu.tw (C.-C.T.); u100003044@cmu.edu.tw (S.-E.T.)

2 School of Pharmacy, China Medical University, No. 91 Hsueh-Shih Rd., Taichung 40402, Taiwan; u108071001@cmu.edu.tw

3 Department of Medico Pharmaceutical Science, Nihon Pharmaceutical University, Komuro Inamachi Kita-adachi-gun, Saitama-ken 10281, Japan; h.takayama@nichiyaku.ac.jp

4 Department of Environmental Science, Nihon Pharmaceutical University, Komuro Inamachi Kita-adachi-gun, Saitama-ken 10281, Japan; uramaru@nichiyaku.ac.jp

5 Institute of New Drug Development, College of Biopharmaceutical and Food Sciences, China Medical University, No. 91 Hsueh-Shih Rd., Taichung 40402, Taiwan; geant@mail.cmu.edu.tw

* Correspondence: wongfungfuh@yahoo.com.tw or ffwong@mail.cmu.edu.tw; Tel.: +886-422-053-366 (ext. 5603); Fax: +886-422-078-083

Academic Editors: Vera L. M. Silva, Artur M. S. Silva and Elena Cariati Received: 28 March 2020; Accepted: 19 May 2020; Published: 21 May 2020 updates

\begin{abstract}
The newly designed luminol structures of pyrazolopyridopyridazine diones and $\mathrm{N}$-aminopyrazolopyrrolopyridine diones were synthesized from versatile 1,3-diaryfuropyrazolopyridine -6,8-diones, 1,3-diarylpyrazolopyrrolopyridine-6,8-diones, or 1,3-diaryl-7- methylpyrazolopyrrolopyridine -6,8-diones with hydrazine monohydrate. Photoluminescent and solvatofluorism properties containing UV-Vis absorption, emission spectra, and quantum yield $\left(\Phi_{\mathrm{f}}\right)$ study of pyrazolopyridopyridazine diones and $\mathrm{N}$-aminopyrazolopyrrolopyridine diones were also studied. Generally, most of pyrazolopyrrolopyridine-6, 8-diones 6 exhibited the significant fluorescence intensity and the substituent effect when compared with $\mathrm{N}$-aminopyrazolopyrrolopyridine diones, particularly for $\mathbf{6 c}$ and $\mathbf{6} \mathbf{j}$ with a $m$-chloro group. Additionally, the fluorescence intensity of $\mathbf{6 j}$ was significantly promoted due to the suitable conjugation conformation. Based on the quantum yield $\left(\Phi_{\mathrm{f}}\right)$ study, the value of compound $\mathbf{6 j}(0.140)$ with planar structural skeletal was similar to that of standard luminol $(\mathbf{1}, 0.175)$.
\end{abstract}

Keywords: pyrazolopyridopyridazine dione; $\mathrm{N}$-aminopyrazolopyrrolopyridine dione; luminol; photoluminescence

\section{Introduction}

Sleep-disorders are one of the largest public health concerns in the whole world [1]. New functionalized pyrazolo $[3,4-b]$ pyrrolo[3,4- $d]$ pyridine derivatives were enthusiastically investigated to develop the increased potency and reduced side effects of novel sedative/hypnotic drug compounds for treatment of sleep-disorders [2,3]. On the other hand, pyrazolopyridopyridazine diones are well-known as the versatile precursors for synthesis of pyrazolopyridopyridazine phosphodiesterase type 5 (PDE5) inhibitors [4,5]. In recent years, chemiluminescent luminol derivatives have been an attractive detection technique in analytical applications such as presumptive test agents for latent blood detection [6-9], high-performance liquid chromatography (HPLC) [10,11], DNA, immunoassay, and cancer screening detection [12,13]. Since now, many newly designed luminol structures have 
been enthusiastically investigated to increase the chemiluminescence efficiency, intensity, sensitivity, quantum yield, or the recognition ability of the resulting chemiluminogens (Figure 1) [14-19].<smiles>Nc1cccc2c(=O)[nH][nH]c(=O)c12</smiles><smiles>[R]c1c(C)cc2cc3c(=O)[nH][nH]c(=O)c3cc2c1[Y]</smiles>

1. Luminol 2. naphthalene and anthracence analogues of luminol<smiles>Cc1nc2ccc3c(=O)[nH][nH]c(=O)c3c2nc1C</smiles>

3. quinoxaline analogues of luminol<smiles>Nc1ccc2c(=O)[nH][nH]c(=O)c2c1</smiles>

4. Isoluminol<smiles>O=c1[nH][nH]c(=O)c2c1ccc1[nH]cnc12</smiles>

5. benzimidazole analogues of luminol

Figure 1. Luminol 1, naphthalene and anthracene 2, quinoxaline analogues of luminol 3, isoluminol 4, and benzimidazole analogues of luminol 5 .

Furthermore, $N$-aminophthalimides were considered as phthalazine 1,4-dione tautomeric pairs [20,21]. $\mathrm{N}$-Amino maleimides with pyridine heterocycle series also presented as a very important privileged substructure in organic synthesis for preparing diverse biologically active molecules [22]. Typically, the most important pharmacological effects that have been reported are potential antimicrobial [22] and anticancer activities [23]. Herein, we judiciously explore the insertion of pyridazinedione and N-Amino maleimide units into the pyrazolopyridine core ring for construction of the new designed luminol structures $\mathbf{6 a}-\mathbf{j}$ and $\mathbf{7 a} \mathbf{a}-\mathbf{i}$ from versatile 1,3-diarylpyrazolopyrrolopyridine-6,8-diones 11. Observably, we found that the series of pyridazinediones $\mathbf{6 a}-\mathbf{j}$ would not only provide conjugation systems but also allow to modify the fluorescence intensity and biological activity (Figure 2).<smiles>[X]c1ccccc1-n1nc([Z])c2c3c(=O)[nH][nH]c(=O)c3cnc21</smiles>

6a-j<smiles>[X]c1cccc(-n2nc([Z])c3c4c(cnc32)C(=O)N(N)C4=O)c1</smiles>

7a-i

Figure 2. Pyrazolopyridopyridazine diones $\mathbf{6 a}-\mathbf{j}$ and $N$-Aminopyrazolopyrrolopyridine diones $\mathbf{7 a}-\mathbf{i}$ as luminol analogues.

\section{Results and Discussion}

Initially, dimethyl 1,3-diphenyl-1H-pyrazolo[3,4-b]pyridine-4,5-dicarboxylate 8 and diethyl 1,3-diphenyl-1H-pyrazolo[3,4-b]pyridine-4,5-dicarboxylate 9 were prepared by following our previously reported literature [24] from $\mathrm{N}, \mathrm{N}$-diisopropylamidinyl pyrazolylimine and chosen as the model substrate for this investigation on the construction of pyrazolopyridopyridazine diones $6 \mathbf{a}$ (Scheme 1). Compounds $\mathbf{8}$ and $\mathbf{9}$ were reacted with hydrazine hydrate at reflux in methanol or ethanol solution under the basic condition for $24-36 \mathrm{~h}[25,26]$. However, all the efforts for the predominant formation of 6a were unsuccessful. We also attempted to perform the hydrolysis of ester groups of compounds $\mathbf{8}$ and 9 under basic conditions to obtain 1,3-diphenyl-1H-pyrazolopyridine-4,5-dicarboxylic acid 10 [27,28]. Subsequently, pyrazolopyridine-4,5-dicarboxylic acid $\mathbf{1 0}$ was refluxed with hydrazine in acetic acid to carry out the cyclization for $8 \mathrm{~h}$, but without success (Scheme 1). 
<smiles>[R]OC(=O)c1cnc2c(c(-c3ccccc3)nn2-c2ccccc2)c1C([R])=O</smiles>

8. $R=M e$

9. $R=E t$ 10. $R=H$

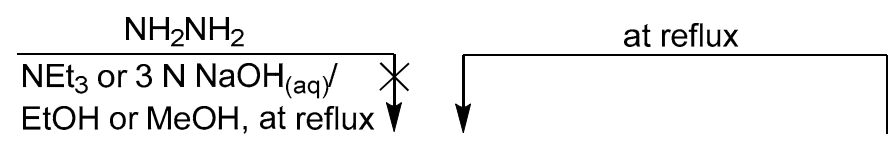<smiles>NN1C(=O)c2cnc3c(c(-c4ccccc4)nn3-c3ccccc3)c2C1=O</smiles><smiles>[X]C(=O)c1cnc2c(c1)c(-c1ccccc1)nn2-c1ccccc1</smiles>

$6 a$ $7 a$

11a. $X=\mathrm{NH}$

12a. $X=$ NMe, 13a. $X=0$

Scheme 1. Synthesis study of pyrazolopyridopyridazine dione $6 \mathbf{a}$ as luminol analogue.

In other attempts, we preliminarily tried to synthesize 1,3-phenylpyrazolopyrrolopyridine-6, 8-dione 11a from $N, N$-diisopropylamidinyl pyrazolylimine with maleimide via our published $\mathrm{InCl}_{3} /$ silica gel catalyzed hetero Diels-Alder reaction [29]. Subsequently, the resulting compound 11a was reacted with an excess of hydrazine hydrate in EtOH/ $\mathrm{H}_{2} \mathrm{O}$ co-solution at room temperature for $\sim 7 \mathrm{~h}[29,30]$. The formation of the $N$-aminopyrazolopyrrolopyridine dione 7 a was observed in $83 \%$ yield as the major product and accompanied with a trace amount of luminol-type pyrazolopyridopyridazine dione $\mathbf{6 a}(<10 \%$, Scheme 1). Fortunately, compounds $\mathbf{6 a}$ and $7 \mathbf{a}$ can be successfully and selectively prepared via kinetic and thermodynamic control reactions [31,32].

For further searching optimal conditions, we also prepared 7-methyl-1,3-phenylpyrazolopyrrolopyridine -6,8-dione 12a [29] and 1,3-diphenylfuropyrazolopyridine-6,8-dione 13a [33,34] as probes for monitoring cyclization tendency with hydrazine hydrate [29,30]. Most of the compounds 11a-13a were refluxed in neat hydrazine hydrate solution for $\sim 5 \mathrm{~h}$ (Scheme 1 and Table 1 ). The reactions were monitored until the consumption of starting materials 11a-13a by TLC and produced the luminol-type pyrazolopyridopyridazine dione 6a. Compound 11a smoothly underwent the cyclization reaction to give luminol-type analogue $\mathbf{6 a}$ in better yield (84\%, Entry 1, Table 1). However, compounds 12a-13a resulted in 32\% and 18\% low yields, respectively (Entries 2 and 3, Table 1). For further demonstration of reactivity efficiency, compounds $\mathbf{1 1 b}-\mathbf{c}, \mathbf{1 2} \mathbf{b}-\mathbf{c}$, and $\mathbf{1 3} \mathbf{b}-\mathbf{c}$ bearing various substituents including $o$ - and $m-\mathrm{Cl}$ in $N$-1-phenyl ring and phenyl at $C-3$ position of pyrazole moiety were synthesized and refluxed under the same condition (Entries 4-9, Table 1). Based on the experimental data of Table 1 , the better yields of pyrazolopyridopyridazine dione products $\mathbf{6 b}-\mathbf{c}$ were provided from 1,3-diarylpyrazolopyrrolopyridine-6,8-diones $\mathbf{1 1 b}-\mathbf{c}(74 \%$ and $71 \%$, Entries 4 and 7, Table 1). Unfortunately, 1,3-diaryl-7-methylpyrazolopyrrolopyridine-6,8-diones 12b-c and 1,3-diarylfuropyrazolopyridine-6,8-diones $\mathbf{1 3 b}-\mathbf{c}$ showed poor reactivity for the formation of pyrazolopyridopyridazine diones $\mathbf{6 b}-\mathbf{c}$ (Entries 5-6 and 8-9, Table 1). 
Table 1. The results of pyrazolopyridopyridazine diones $\mathbf{6 a}-\mathbf{j}$ from reactants $11 \mathbf{a}-\mathbf{j}, \mathbf{1 2} \mathbf{a}-\mathbf{c}$, or $13 \mathbf{a}-\mathbf{c}$ with hydrazine hydrate.

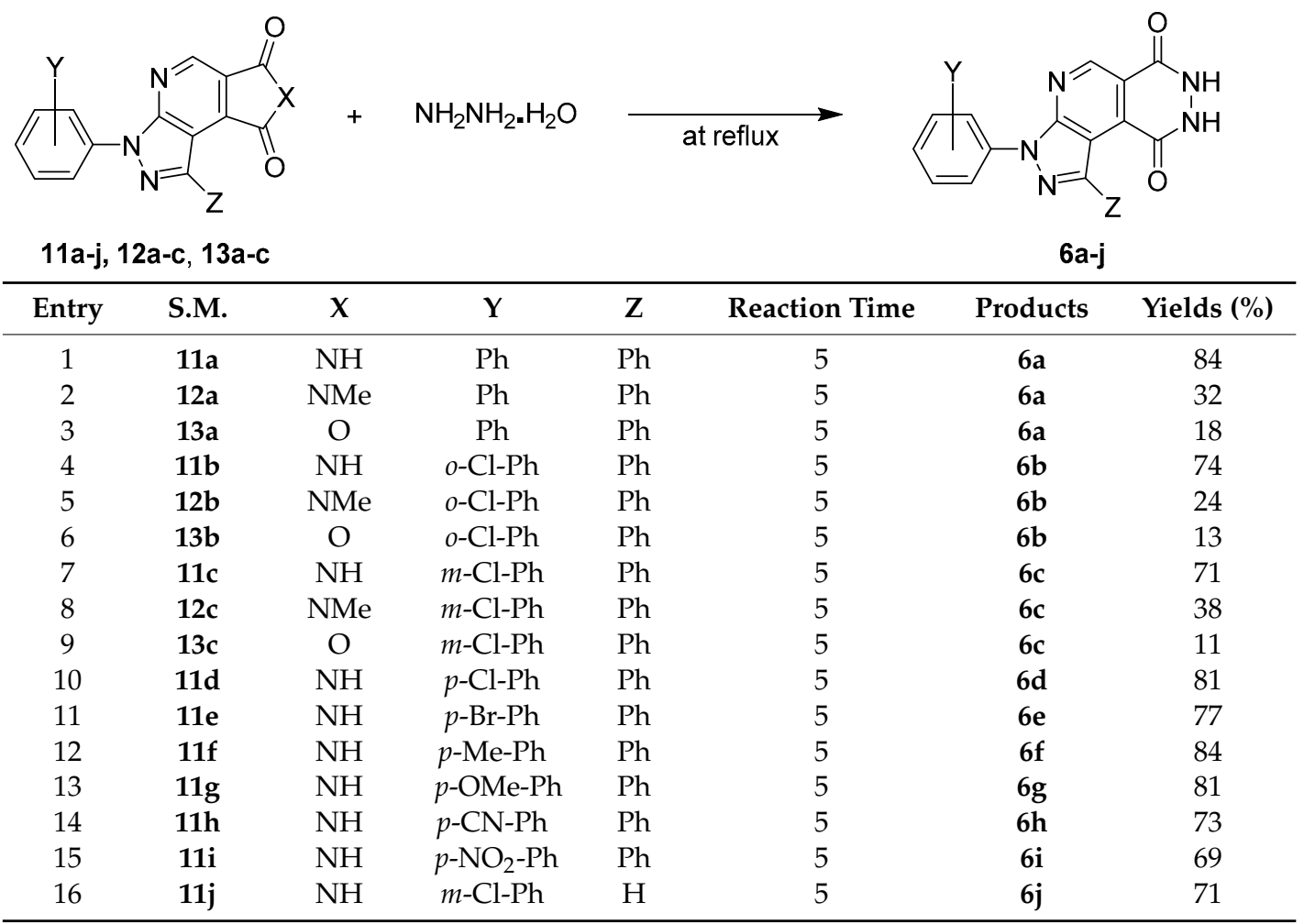

Furthermore, we applied this reliable procedure to reactants $11 \mathbf{d}-\mathbf{j}$ bearing $p-\mathrm{Cl}-\mathrm{Ph}, p-\mathrm{Br}-\mathrm{Ph}$, $p$-Me-Ph, $p$-OMe-Ph, $p$-CN-Ph, $p-\mathrm{NO}_{2}-\mathrm{Ph}$, and $m-\mathrm{Cl}-\mathrm{Ph}$ at the $\mathrm{N}-1$ position and phenyl and $\mathrm{H}$ at $C-3$ position of pyrazolic ring. Various substituted reactants $\mathbf{1 1} \mathbf{d}-\mathbf{j}$ were demonstrated to proceed smoothly. Both electron-donating and electron-withdrawing substituents were all well-tolerated in good yields (69-84\%, Entries 10-16, Table 1). All of 1,3-diarylpyrazolopyrrolopyridine-6,8-diones $\mathbf{6 a}-\mathbf{j}$ were fully characterized by spectroscopic methods. For example, compound 6a presented one singlet at $\delta 9.41$ ppm for pyrazolopyridine ring $\mathrm{N}=\mathrm{CH}-\mathrm{C}=\mathrm{C}$ in ${ }^{1} \mathrm{H}-\mathrm{NMR}$ and two peaks at $\delta 153.1$ and $155.7 \mathrm{ppm}$ for pyridazine dione carbon $\mathrm{O}=\mathrm{C}-\mathrm{NH}$ in ${ }^{13} \mathrm{C}-\mathrm{NMR}$ spectrum. Its IR absorptions showed peaks at $3161 \mathrm{~cm}^{-1}$ for stretching of the $-\mathrm{NH}$ group and at $1014 \mathrm{~cm}^{-1}$ for stretching of the N-N group.

For the further controlled experiment for photoluminescence study, we also tried to prepare a series of $\mathrm{N}$-aminopyrazolopyrrolopyridine diones $\mathbf{7 a - i}$ as the comparison cases (Scheme 2). Treatment of pyrazolopyrrolopyridine-6,8-diones 11a-i with 5.0 equivalents of hydrazine hydrate in $\mathrm{EtOH} / \mathrm{H}_{2} \mathrm{O}$ co-solution was performed in an ice-bath to room temperature for $48 \mathrm{~h}$. The corresponding $\mathrm{N}$-aminopyrazolopyrrolopyridine diones $7 \mathbf{a}-\mathbf{i}$ were obtained in $71-87 \%$ yields and characterized by spectroscopic methods. For example, compound 7a presented one singlet peak at $\delta 8.83 \mathrm{ppm}$ for pyrazolopyridine ring $\mathrm{N}=\mathrm{CH}-\mathrm{C}=\mathrm{C}$ in ${ }^{1} \mathrm{H}-\mathrm{NMR}$ and two peaks at $\delta 164.1$ and $164.4 \mathrm{ppm}$ for phthalimide moiety carbon $\mathrm{O}=\mathrm{C}-\mathrm{NH}$ in ${ }^{13} \mathrm{C}-\mathrm{NMR}$ spectrum. Its $\mathrm{IR}$ absorptions showed peaks at 3172 and $3276 \mathrm{~cm}^{-1}$ for stretching of the $-\mathrm{NH}_{2}$ group and at $1014 \mathrm{~cm}^{-1}$ for stretching of the $\mathrm{N}-\mathrm{N}$ group. Due to the structural skeletons being very similar between 6 and 7 , the identify method should be our next future evaluation. 


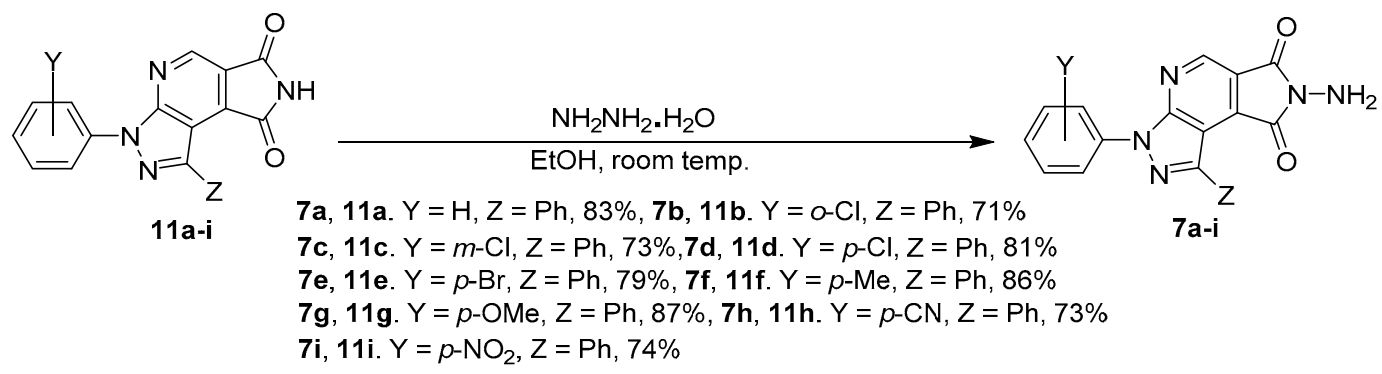

Scheme 2. The results of $N$-aminopyrazolopyrrolopyridine diones $7 \mathbf{a}-\mathbf{i}$ from pyrazolopyrrolopyridine- 6 , 8-diones 11a-i with hydrazine hydrate.

Luminol (1), compounds $\mathbf{6 a}$ and $7 \mathbf{a}$ were dissolved in DMSO to prepare a stock solution $\left(1 \times 10^{-3} \mathrm{M}\right)$. Then the stock solutions of compounds $6 \mathbf{a}$ and $7 \mathbf{a}$ were individually diluted to a concentration of $10 \mu \mathrm{M}$ in the presence of various solvents such as toluene, THF, ethyl acetate (EA), $\mathrm{CH}_{2} \mathrm{Cl}_{2}, \mathrm{MeCN}$, acetone, and DMSO. The standard stock solution of luminol $(10 \mu \mathrm{M})$ was diluted in DMSO solution as the standard sample. The UV-Vis absorption and fluorescence emission spectra of the pyrazolopyridopyridazine dione $\mathbf{6 a}$ and $\mathrm{N}$-aminopyrazolopyrrolopyridine dione 7 a compounds in the above-mentioned solution of varying polarities were reported in Table 2. The pyrazolopyridopyridazine dione $\mathbf{6 a}$ has better solubility in polar organic solvents, such as DMSO $>$ THF $>$ acetone, but $N$-aminopyrazolopyrrolopyridine dione $7 \mathbf{a}$ has the solubility only in highly polar solvents like DMSO. Luminol (1) was also measured and used as the standard sample. The UV-Vis absorption spectra of the compounds $6 \mathbf{a}$ and $7 \mathbf{a}$ in all the studied solvents were almost nearly the same; their absorption property is independent of the solvent polarity (Figure 3 and Table 2). All these compounds exhibit two highly intense absorption maxima peaks. Among these two, the first one was a high energy absorption between $253 \mathrm{~nm}$ and $286 \mathrm{~nm}$ for $6 \mathbf{a}$ and 7a probably due to the $\pi-\pi^{*}$ transition of the aryl core [35] while the low energy band between $329 \mathrm{~nm}$ and $366 \mathrm{~nm}$ is attributed to the intramolecular charge transfer transition (ICT). However, the rigidity in the structure of compounds 6a and 7a exhibited the stronger blue-shifted absorption $(\sim 15 \mathrm{~nm})$ than luminol (1) in DMSO solution, as shown in Figure 3 and Table 2. In comparison with $\mathbf{6 a}$ and $\mathbf{7 a}$, they demonstrated a similar absorption intensity, and compound $6 \mathbf{a}$ has obvious red-shift $\sim 20 \mathrm{~nm}$ with respect to $7 \mathbf{a}$.

Table 2. UV-Vis absorption maximum and fluorescence emission peak wavelength of luminol (1), pyrazolopyridopyridazine dione $\mathbf{6 a}$ and $\mathrm{N}$-aminopyrazolopyrrolopyridine dione $\mathbf{7 a}$ in the different solvents.

\begin{tabular}{cccc}
\hline Compound & Solvent & $\lambda$ max/nm of UV-Vis & $\lambda$ max/nm of PL \\
\hline $\mathbf{6 a}$ & Toluene & $-1,366$ & 469 \\
$\mathbf{6 a}$ & $\mathrm{THF}$ & 271,358 & 471 \\
$\mathbf{6 a}$ & Ethyl acetate & 268,356 & 473 \\
$\mathbf{6 a}$ & $\mathrm{CH}_{2} \mathrm{Cl}_{2}$ & 271,350 & 483 \\
$\mathbf{6 a}$ & $\mathrm{MeCN}$ & 268,351 & 488 \\
$\mathbf{6 a}$ & $\mathrm{Acetone}$ & $-1,353$ & 477 \\
$\mathbf{6 a}$ & $\mathrm{DMSO}$ & 264,338 & 486 \\
$\mathbf{7 a}$ & Toluene & $286,1,348$ & 452 \\
$\mathbf{7 a}$ & $\mathrm{THF}$ & 264,344 & 454 \\
$\mathbf{7 a}$ & Ethyl acetate & 262,343 & 459 \\
$\mathbf{7 a}$ & $\mathrm{CH} \mathrm{H}_{2}$ & 264,344 & 471 \\
$\mathbf{7 a}$ & $\mathrm{MeCN}$ & 261,329 & 425,461 \\
$\mathbf{7 a}$ & $\mathrm{Acetone}$ & $-1,338$ & 452 \\
$\mathbf{7 a}$ & $\mathrm{DMSO}$ & 264,335 & 429,478 \\
Luminol $(\mathbf{1})$ & DMSO & 350 & 392 \\
\hline
\end{tabular}

${ }^{1}$ It was overlapped with solvent absorption band. 
(A)
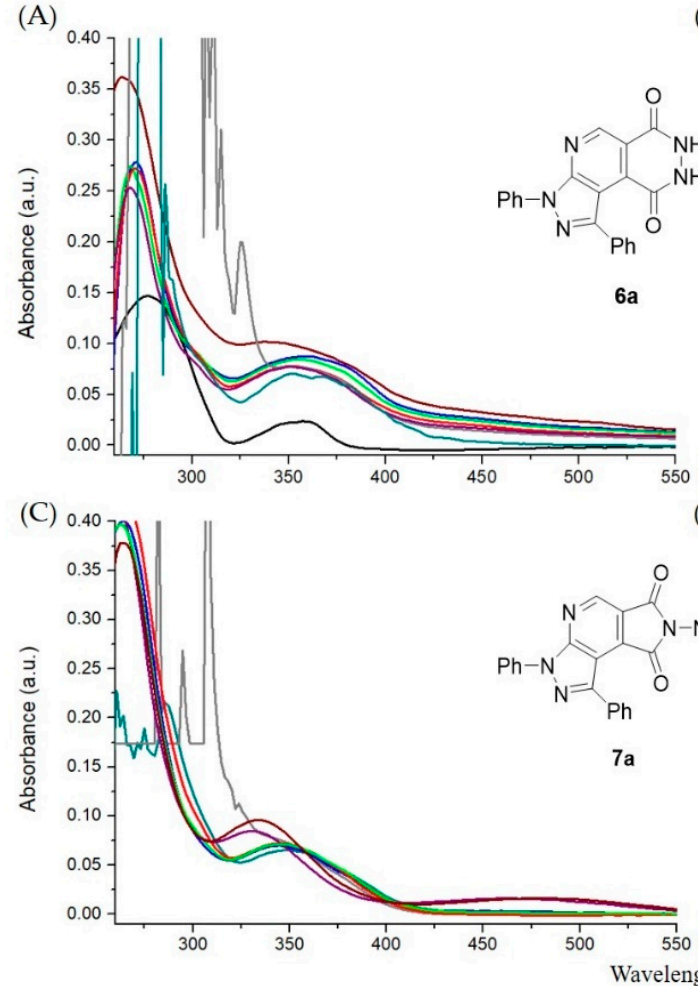

(B)

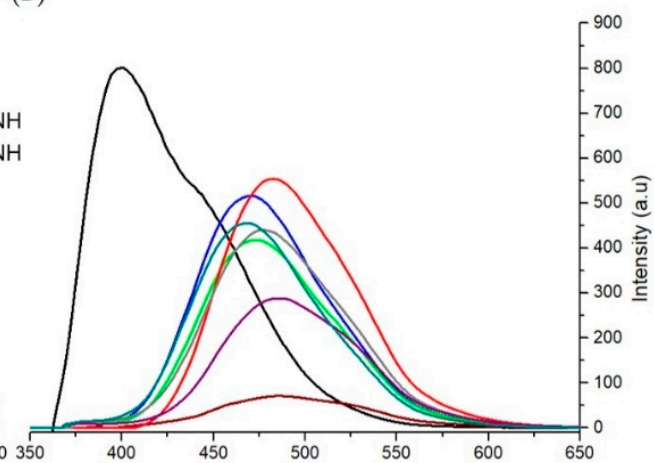

(D)

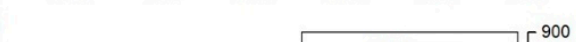

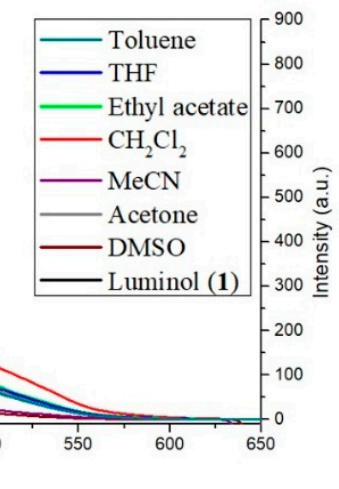

Figure 3. Photoluminescence spectra of luminol (1), pyrazolopyridopyridazine dione $\mathbf{6 a}$ and $\mathrm{N}$-aminopyrazolopyrrolopyridine dione $\mathbf{7 a}$ in the different solvents. (A) Absorption and (B) emission spectra of luminol (1) and compound 6a. (C) Absorption and (D) emission spectra of compound 7a.

Consequently, we investigated the photoluminescence properties of the compounds $6 \mathbf{a}$ and $7 \mathbf{a}$ with luminol (1). For the fluorescence spectra, as shown in Figure 3 and Table 2, both the fluorescence intensity and the maximal position slightly varied depending on the solvent. Compound $6 \mathbf{a}$ displayed a characteristic emission band of the excitation wavelengths between 400 and $600 \mathrm{~nm}$, and the $\lambda_{\max } \mathrm{s}$ of PL was $\sim 480 \mathrm{~nm}$ with the intense greenish-blue fluorescence in Figures 3 and 4 . For compound $7 \mathbf{a}$, it's emission spectrum was between 350 and $550 \mathrm{~nm}$, and the $\lambda_{\max } \mathrm{s}$ of PL was $\sim 450 \mathrm{~nm}$ with the intense bluish-green fluorescence in Figures 3 and 4. Compounds $6 \mathbf{a}$ and $7 \mathbf{a}$ exhibited a red-shift $\sim 80 \mathrm{~nm}$ or $\sim 60 \mathrm{~nm}$ as compared to luminol (1). Therefore, new luminol analogues $6 \mathbf{a}$ and $7 \mathbf{a}$ were efficiently conjugate and connect two chromophores (pyrazole and pyridine) to lead to an increase of aromaticity and provide the greenish-blue or bluish-green fluorescent materials (Table 2 and Figure 4) [36]. Particularly, the best positive solvatofluorism phenomenon was presented in $\mathrm{CH}_{2} \mathrm{Cl}_{2}$ solution. It was also beneficial for the visibility of the naked eye due to the bathochromic (red-shift) phenomenon from blue color to green (Figure 4). 


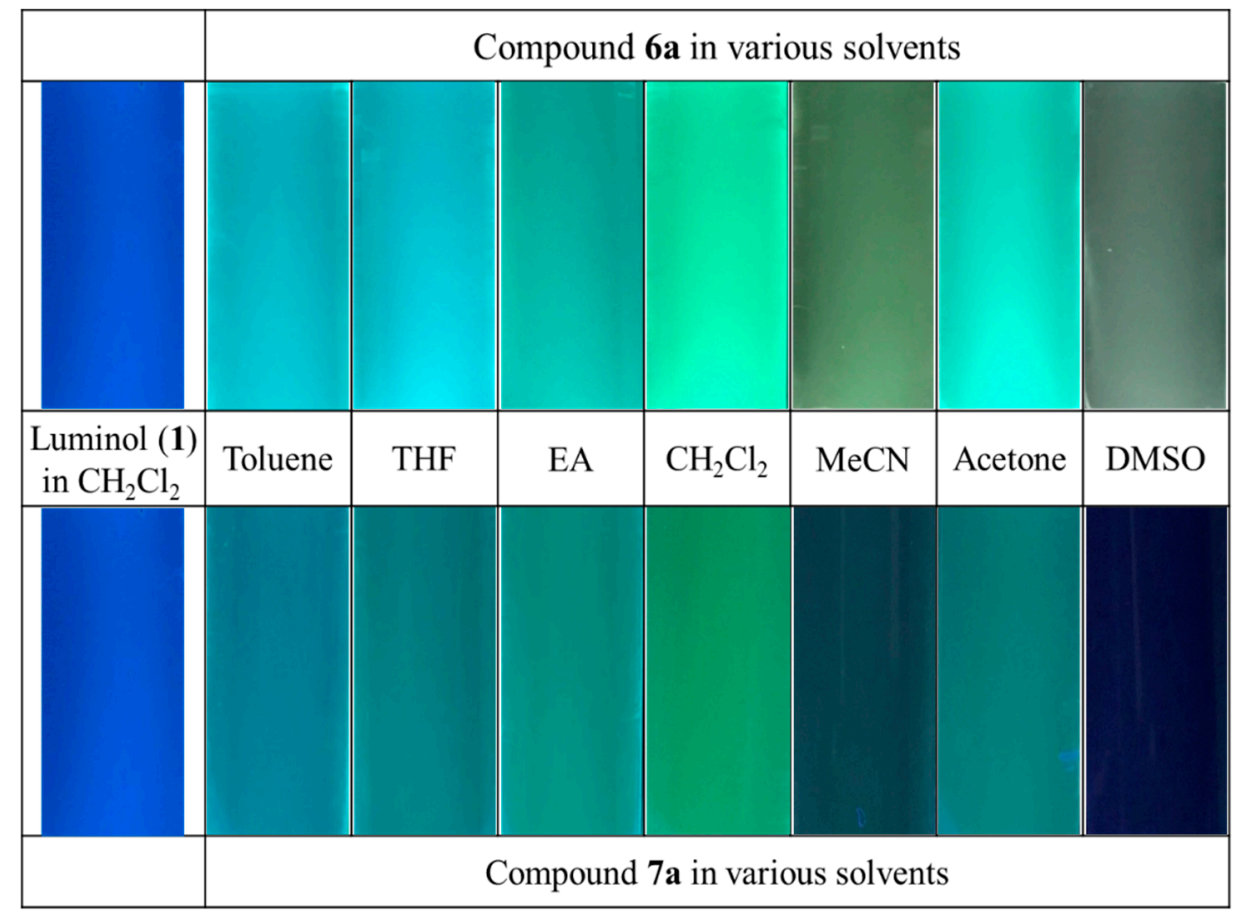

Figure 4. Color pictures of the fluorescence of compounds $6 \mathbf{a}$ and $7 \mathbf{a}$ in various solvents under excitation at $365 \mathrm{~nm}$.

Moreover, the maximum of fluorescence wavelength and intensity, as shown in Figure 3, significantly vary with the diluted solvent. Further, we surprisingly observed the more significant solvent effect on compound 6a when compared with compound 7a. As shown in Figure 3, similar fluorescence spectra but a significant difference in intensity ( $\sim 6$ times) were observed in varying solvents. Of note, it was interesting that toluene, THF, EA, and $\mathrm{CH}_{2} \mathrm{Cl}_{2}$ had differences in their polarity (toluene: 0.099 , THF: 0.207 , EA: $0.228, \mathrm{CH}_{2} \mathrm{Cl}_{2}: 0.309$, with respect to the reference polarity of DMSO: $0.444)[37,38]$. However, for the above solvents, we observed a strong intensity, in comparison to that for protic or/and polar solvent (DMSO). The intensities of fluorescence bands were reversed in protic or/and polar solvents. Therefore, the solvent polarity modulation of fluorescence was quite interesting. It was well studied that amide tautomer of pyrazolopyridopyridazine dione $\mathbf{6} \mathbf{a}$ was efficiently produced in toluene, THF, EA, and $\mathrm{CH}_{2} \mathrm{Cl}_{2}$ solvents [39-44]. In alcoholic (protic) and DMSO solvent, there exists competition between intermolecular bonding of the nearest hydrogen with the hydroxyimine tautomer of 6-hydroxypyrazolopyridopyridazin-9-one 6a. Therefore, different intensities of behavior were observed in different polarity solutions. On the other hand, the different fluorescence intensity between structural isomers $\mathbf{6 a}$ and $7 \mathbf{a}$ was also observed [45]. The aromaticity of compound $\mathbf{6 a}$ possessed the bathochromic shift of fluorescence maximum $\lambda_{\max }$ by $12 \mathrm{~nm}$ and $\sim 4$ times significant intensity in $\mathrm{CH}_{2} \mathrm{Cl}_{2}$ solution when compared with compound 7a (Table 2 and Figure 3) [46]. However, the intramolecular and intermolecular hydrogen bondings between the amino and carbonyl groups of $\mathrm{N}$-aminopyrazolopyrrolopyridine dione 7 a were formed to lead to the poor intensity in solution.

For further investigation of substituent efficiency of compounds 6 and 7 in photoluminescence properties, we synthesized a series of pyrazolopyridopyridazine diones $\mathbf{6} \mathbf{a}-\mathbf{j}$ and $N$-aminopyrazolo pyrrolopyridine diones $7 \mathbf{a}-\mathbf{i}$ bearing various substituents including $o-, m$ - and $p-\mathrm{Cl}, p-\mathrm{Br}, p-\mathrm{Me}, p-\mathrm{OMe}$, $p-\mathrm{CN}$, and $p-\mathrm{NO}_{2}$ groups in N1-phenyl ring of pyrazole moiety. Generally, most of the substituents such as $0-, m$ - and $p-\mathrm{Cl}, p-\mathrm{Br}, p-\mathrm{Me}$, and $p$-CN in N1-phenyl of pyrazolic ring of compounds 6 possessed the blue-shift phenomenon range $\sim 10$ to $30 \mathrm{~nm}$ with significant fluorescence intensity when compared with compound $\mathbf{6 a}$, particularly for $\mathbf{6} \mathbf{c}$ with meta-chloro group (Figure 5). For compounds $\mathbf{6} \mathbf{g}$ and $\mathbf{6} \mathbf{i}$ with the strong electron-donating $(p-\mathrm{OMe})$ or electron-withdrawing groups $\left(p-\mathrm{NO}_{2}\right)$, they exhibited negative photoluminescence properties (Figure 5). While we modified the skeletal structure of 
pyrazolopyridopyridazine dione $\mathbf{6 j}$, in which Ph-group was replaced to $\mathrm{H}$ atom on $\mathrm{C}-3$ position of pyrazolic ring, the blue-shift phenomenon was remarkably observed in photoluminescence spectra. Additionally, the fluorescence intensity of $\mathbf{6} \mathbf{j}$ was significantly promoted about 2.3 times in comparison with compound 6a (Figure 5). Based on the result of the substituent study, we conceived that compound $\mathbf{6 j}$ was an effective substrate that possessed suitable conjugation conformation without the torsion effect to facilitate the photoluminescence properties [26]. For compounds 7a-i bearing the above various substituents, they provided the weak fluorescence intensity [45] and possessed the blue-shift phenomenon when compared with $\mathbf{7 a}$, except for $\mathbf{7 c}$ with $m$-chloro group and $\mathbf{7 h}$ with $p$-CN group (Figure 6). Generally, compounds $7 \mathbf{a}-\mathbf{i}$ were the inappropriate photoluminescent substrates [45].

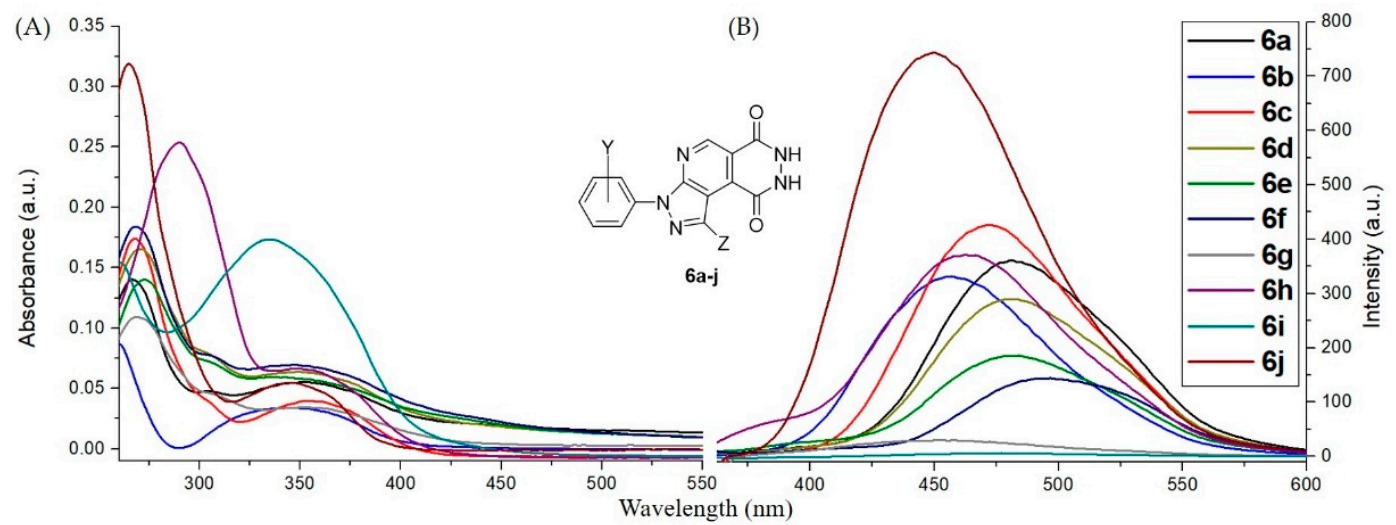

Figure 5. Photoluminescence spectra of pyrazolopyridopyridazine diones $\mathbf{6 a}-\mathbf{j}$ dissolved in DMSO to prepare a stock solution $(1.0 \mathrm{mM})$. Then the stock solutions were diluted with $\mathrm{CH}_{2} \mathrm{Cl}_{2}$ to a concentration of $10 \mu \mathrm{M}$. (A) Absorption and (B) emission spectra of compounds $\mathbf{6 a}-\mathbf{j}$.

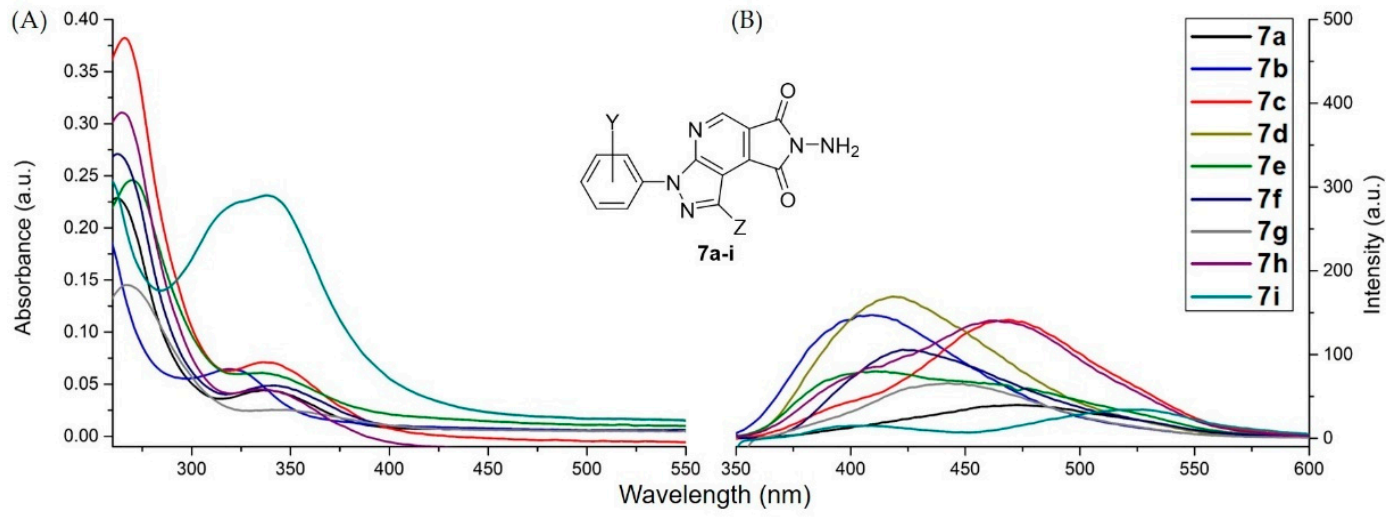

Figure 6. Photoluminescence spectra of $\mathrm{N}$-aminopyrazolopyrrolopyridine diones $7 \mathrm{a}-\mathbf{i}$ dissolved in DMSO to prepare a stock solution $(1.0 \mathrm{mM})$. Then the stock solutions were diluted with $\mathrm{CH}_{2} \mathrm{Cl}_{2}$ to a concentration of $10 \mu \mathrm{M}$. (A) Absorption and (B) emission spectra of compounds $7 \mathbf{a}-\mathbf{i}$.

The quantum yields $\left(\Phi_{\mathrm{f}}\right)$ of luminol (1) and pyrazolopyridopyridazine diones $\mathbf{6 a}, \mathbf{6} \mathbf{c}$, and $\mathbf{6 j}$ were measured in the $\mathrm{CH}_{2} \mathrm{Cl}_{2}$ solution using quinine sulfate in $0.05 \mathrm{M} \mathrm{H}_{2} \mathrm{SO}_{4}\left(\Phi_{\mathrm{f}}=0.60\right)$ as the standard (excitation wavelength $350 \mathrm{~nm}$ ) [47,48]. The quantum yields $\left(\Phi_{\mathrm{f}}\right)$ values of luminol (1) and pyrazolopyridopyridazine diones $\mathbf{6 a}, \mathbf{6 c}$, and $\mathbf{6} \mathbf{j}$ were estimated as $0.175,0.056,0.067$, and 0.140 in $\mathrm{CH}_{2} \mathrm{Cl}_{2}$ solution, respectively, indicating that the $\Phi_{\mathrm{f}}$ value of $\mathbf{6 j}$ was similar to that of luminol $\mathbf{( 1}$, Table 3). Moreover, we also investigated the quantum yields of $\mathbf{6} \mathbf{j}$ in various solvents by using the same condition. The estimated values order trendy was as 0.218 (THF) $>0.209$ (Toluene) $>0.140$ $\left(\mathrm{CH}_{2} \mathrm{Cl}_{2}\right)>0.083$ (acetone) $>0.049(\mathrm{EA})$, indicating THF provided the largest $\Phi_{\mathrm{f}}$ value among them (Table 3). On the other hand, most of the quantum yields $\left(\Phi_{\mathrm{f}}\right)$ pyrazolopyridopyridazine diones $\mathbf{6 a}-\mathbf{i}$ in $\mathrm{CH}_{2} \mathrm{Cl}_{2}$ solution were predicted to be an almost identical value (ca. 0.05-0.06). Interestingly, the high 
$\Phi_{\mathrm{f}}$ value of $\mathbf{6} \mathbf{j}$ was obtained and possibly caused by a particular improvement in the planar skeletal conformation (Table 3 and Figure 7).

Table 3. Quantum yields of fluorescence of luminol (1) and pyrazolopyridopyridazine diones $\mathbf{6 a}, \mathbf{6 c}$, and $6 \mathbf{j}$.

\begin{tabular}{cccc}
\hline Compound & Solvent & $\boldsymbol{\lambda}_{\mathbf{f l}} \mathbf{1} / \mathbf{n m}$ & $\mathbf{\Phi}_{\mathbf{f}}{ }^{\mathbf{2}}$ \\
\hline $\mathbf{6 a}$ & $\mathrm{CH}_{2} \mathrm{Cl}_{2}$ & 481 & 0.056 \\
$\mathbf{6 c}$ & $\mathrm{CH}_{2} \mathrm{Cl}_{2}$ & 472 & 0.067 \\
$\mathbf{6 j}$ & $\mathrm{CH}_{2} \mathrm{Cl}_{2}$ & 450 & 0.140 \\
$\mathbf{6 j}$ & $\mathrm{THF}$ & 435 & 0.218 \\
$\mathbf{6 j}$ & Toluene & 438 & 0.209 \\
$\mathbf{6 j}$ & Acetone & 437 & 0.083 \\
$\mathbf{6 j}$ & Ethyl acetate & 437 & 0.049 \\
Luminol (1) & $\mathrm{CH}_{2} \mathrm{Cl}_{2}$ & 399 & 0.175 \\
\hline
\end{tabular}

${ }^{1}$ Fluorescence maximum wavelength $\left(\lambda_{\mathrm{fl}}\right) .{ }^{2} \Phi_{\mathrm{f}}$ : Fluorescence quantum efficiency, relative to quinine sulfate $\left(\Phi_{\mathrm{f}}=0.60\right)$.

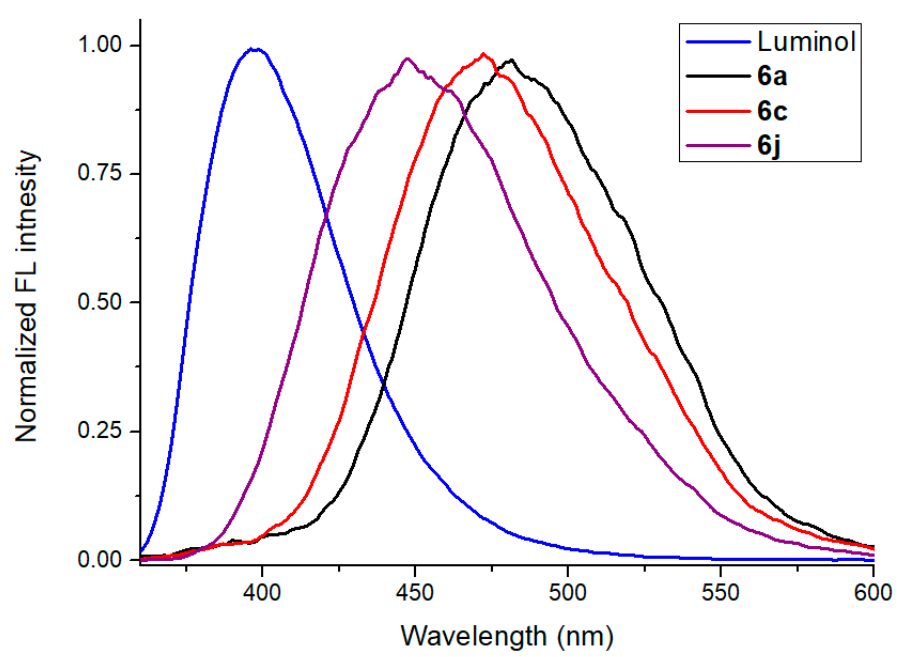

Figure 7. Normalized fluorescence spectra of luminol and pyrazolopyridopyridazine diones $\mathbf{6 a}, \mathbf{6 c}$, and $\mathbf{6 j}$ in the $\mathrm{CH}_{2} \mathrm{Cl}_{2}$ solution (excitation wavelength $350 \mathrm{~nm}$ ).

\section{Experimental Section}

\subsection{General Information}

All reagents were used as obtained commercially. All reactions were carried out under argon or nitrogen atmosphere and monitored by thin-layer chromatography (TLC). Flash column chromatography was carried out on silica gel (230-400 mesh). Analytical thin-layer chromatography was performed using pre-coated plates (silica gel 60 F-254) purchased from Merck Inc. Flash column chromatography purification was carried out by gradient elution using $n$-hexane in ethyl acetate (EtOAc) unless otherwise stated. ${ }^{1} \mathrm{H}-\mathrm{NMR}$ was recorded at 400, 500, or $600 \mathrm{MHz}$ and ${ }^{13} \mathrm{C}-\mathrm{NMR}$ recorded at 100,125 , or $150 \mathrm{MHz}$, respectively, in DMSO- $d_{6}$ as the solvent. The standard abbreviations s, $d, t, q$, and $\mathrm{m}$ refer to the singlet, doublet, triplet, quartet, and multiplet, respectively. Coupling constant $(J)$, whenever discernible, have been reported in Hz. Infrared spectra (IR) were recorded as neat solutions or solids; mass spectra were recorded using electron impact or electrospray ionization techniques. The wavenumbers reported are referenced to the polystyrene $1601 \mathrm{~cm}^{-1}$ absorption. ESI-MS analyses were performed on an Applied Biosystems API 300 mass spectrometer. High-resolution mass spectra (HRMS) were recorded on a JEOL JMS-HX110 mass spectrometer with an electron ionization (EI) source The UV-visible absorption and emission spectra were performed on a Perkin-Elmer Lambda 265 and Perkin-Elmer LS50B, a fused quartz cuvette $(10 \mathrm{~mm} \times 10 \mathrm{~mm})$ at room temperature, respectively. 
Quantum yields were obtained by using quinine sulfate (0.60 in $\left.0.05 \mathrm{M} \mathrm{H}_{2} \mathrm{SO}_{4}\right)$ as a reference. Stock solutions $\left(1 \times 10^{-3} \mathrm{M}\right)$ of luminol (1), compounds of $\mathbf{6 a}-\mathbf{j}$ and $\mathbf{7 a} \mathbf{a}-\mathbf{i}$ were prepared in dimethyl sulfoxide (DMSO).

\subsection{Standard Procedure for Synthesis of Pyrazolopyridopyridazine Diones $\mathbf{6 a}-\mathbf{j}$}

The reliable procedure involved the treatment of 1,3-diarylpyrazolopyrrolopyridine-6,8-diones (11a-j), 1,3-diaryl-7-methylpyrazolopyrrolopyridine-6,8-diones (12a-c) 1,3-diarylfuropyrazolopyridine-6, 8-diones (13a-c, 1.0 equiv.) with hydrazine monohydrate ( $\sim 40$ equiv.) in neat solution at reflux for $5 \mathrm{~h}$. When the reaction was completed, the reaction mixture was added to water $(10 \mathrm{~mL})$ for precipitation. The precipitate was filtered, washed with cold water $(10 \mathrm{~mL})$, and $n$-hexane/EA $(1 / 2,15 \mathrm{~mL})$ to give the corresponding crude pyrazolopyridopyridazine diones $\mathbf{6} \mathbf{a}-\mathbf{j}$. The crude desired products $6 \mathbf{a}-\mathbf{j}$ were recrystallized in acetone/THF (1/4) solution to obtain the pure pyrazolopyridopyridazine diones $\mathbf{6 a}-\mathbf{j}$ in $11-84 \%$ yields. The low solubility of the compounds $6 \mathbf{a}-\mathbf{j}$ made the ${ }^{13} \mathrm{C}-\mathrm{NMR}$ characterization of quaternary and carbonyl carbons of these substrates unclear $[25,26]$.

1,3-Diphenyl-7,8-dihydro-3H-pyrazolo[4', 3':5,6]pyrido[3,4-d]pyridazine-6,9-dione (6a), Light yellow solid; yield: 84\%; mp 292-295 ${ }^{\circ} \mathrm{C} .{ }^{1} \mathrm{H}-\mathrm{NMR}$ (DMSO- $\left.d_{6}, 600 \mathrm{MHz}\right) \delta 7.43-7.47$ (m, 4H, ArH), 7.60-7.64 $(\mathrm{m}, 4 \mathrm{H}, \operatorname{ArH}), 8.20(\mathrm{~d}, J=7.9 \mathrm{~Hz}, 2 \mathrm{H}, \operatorname{ArH}), 9.43(\mathrm{~s}, 1 \mathrm{H}, \operatorname{ArH}), 10.20(\mathrm{br}, 1 \mathrm{H}, \mathrm{NH}) ;{ }^{13} \mathrm{C}\left\{{ }^{1} \mathrm{H}\right\} \mathrm{NMR}$ (DMSO-d $\left.d_{6}, 150 \mathrm{MHz}\right) \delta 109.55,122.46(2 \times \mathrm{CH}), 126.67,127.16,127.78,129.26(2 \times \mathrm{CH}+2 \times \mathrm{CH}), 130.21$ $(2 \times \mathrm{CH}+\mathrm{CH}), 134.99,138.16,147.54,149.49,151.35,153.28,155.21 ;$ FT-IR (KBr) v: 3161, 3033, 2907,

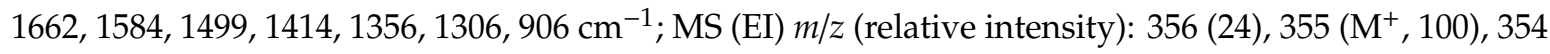
(27), 270 (24), 269 (12), 268 (12), 77 (39); HRMS (EI) m/z: [M] ${ }^{+}$Calcd for $\mathrm{C}_{20} \mathrm{H}_{13} \mathrm{~N}_{5} \mathrm{O}_{2}$ : 355.1069; found: 355.1065 .

3-(2-Chlorophenyl)-1-phenyl-7,8-dihydro-3H-pyrazolo[ $\left.4^{\prime}, 3^{\prime}: 5,6\right]$ pyrido[3,4-d]pyridazine-6,9-dione (6b), Yellow-brown solid; yield: 74\%; mp 332-335 ${ }^{\circ} \mathrm{C} ;{ }^{1} \mathrm{H}-\mathrm{NMR}$ (DMSO- $\left.d_{6}, 500 \mathrm{MHz}\right) \delta 7.40(\mathrm{br}, 3 \mathrm{H}, \mathrm{ArH})$, 7.60-7.61 (m, 2H, ArH), $7.63(\mathrm{~d}, J=7.5 \mathrm{~Hz}, 1 \mathrm{H}, \mathrm{ArH}), 7.67(\mathrm{t}, J=7.5 \mathrm{~Hz}, 1 \mathrm{H}, \operatorname{ArH}), 7.79-7.80(\mathrm{~m}, 2 \mathrm{H}$, $\mathrm{ArH}), 9.35$ (s, $1 \mathrm{H}, \mathrm{ArH}) ;{ }^{13} \mathrm{C}\left\{{ }^{1} \mathrm{H}\right\} \mathrm{NMR}\left(\mathrm{DMSO}-d_{6}, 125 \mathrm{MHz}\right) \delta 109.33,124.53,126.66,127.77,128.01$, 128.18, 128.45, $130.23(2 \times \mathrm{CH}), 130.30,130.47,131.33,131.36,134.73,134.94,147.84,149.81,152.65$, 155.49, 156.94; FT-IR (KBr) v: 3427, 3281, 3060, 2921, 1621, 1561, 1508, 1430, 1351, $905 \mathrm{~cm}^{-1}$; MS (EI) $\mathrm{m} / \mathrm{z}$ (relative intensity): $391\left(\mathrm{M}^{+}+2,29\right), 390$ (22), $389\left(\mathrm{M}^{+}, 100\right), 355$ (12), 354 (52), 304 (15), 268 (17), 111 (13), 77 (44); HRMS (EI) $m / z$ : [M] ${ }^{+}$Calcd for $\mathrm{C}_{20} \mathrm{H}_{12} \mathrm{ClN}_{5} \mathrm{O}_{2}$ : 389.0680; found: 389.0678.

3-(3-Chlorophenyl)-1-phenyl-7,8-dihydro-3H-pyrazolo[4',3':5,6]pyrido[3,4-d]pyridazine-6,9-dione (6c), Yellow solid; yield: 71\%; mp 228-229 ${ }^{\circ} \mathrm{C} ;{ }^{1} \mathrm{H}-\mathrm{NMR}$ (DMSO- $\left.d_{6}, 500 \mathrm{MHz}\right) \delta 7.42-7.43(\mathrm{~m}, 3 \mathrm{H}, \mathrm{ArH}), 7.50$ $(\mathrm{d}, J=6.7 \mathrm{~Hz}, 1 \mathrm{H}, \mathrm{ArH}), 7.60(\mathrm{~d}, J=5.2 \mathrm{~Hz}, 2 \mathrm{H}, \operatorname{ArH}), 7.64(\mathrm{t}, J=8.0 \mathrm{~Hz}, 1 \mathrm{H}, \operatorname{Ar} H), 8.26(\mathrm{~d}, J=8.0 \mathrm{~Hz}$, $1 \mathrm{H}, \mathrm{ArH}), 8.34(\mathrm{~s}, 1 \mathrm{H}, \mathrm{ArH}), 9.44(\mathrm{~s}, 1 \mathrm{H}, \mathrm{ArH}), 12.06(\mathrm{br}, 1 \mathrm{H}, \mathrm{NH}) ;{ }^{13} \mathrm{C}\left\{{ }^{1} \mathrm{H}\right\} \mathrm{NMR}$ (DMSO-d $\left.{ }_{6}, 125 \mathrm{MHz}\right)$ $\delta$ 107.59, 119.56, 120.40, 121.43, $126.72(3 \times \mathrm{CH}), 127.93,130.14(2 \times \mathrm{CH}+1 \times \mathrm{C}), 130.99,133.49,134.67$, 139.34, 148.03, 149.66, 151.53, 155.16, 157.57; FT-IR (KBr) v: 3453, 3344, 3296, 1651, 1595, $1483 \mathrm{~cm}^{-1}$; MS (EI) $\mathrm{m} / \mathrm{z}$ (relative intensity): $391\left(\mathrm{M}^{+}+2,33\right), 390(27), 389\left(\mathrm{M}^{+}, 100\right), 388$ (14), 304 (14), 111 (11), 77 (17); HRMS (EI) $m / z$ : [M] ${ }^{+}$Calcd for $\mathrm{C}_{20} \mathrm{H}_{12} \mathrm{ClN}_{5} \mathrm{O}_{2}$ : 389.0680; found: 389.0686 .

3-(4-Chlorophenyl)-1-phenyl-7,8-dihydro-3H-pyrazolo[4',3':5,6]pyrido[3,4-d]pyridazine-6,9-dione (6d), Light yellow solid; yield: 81\%; mp 339-341 ${ }^{\circ} \mathrm{C}$; ${ }^{1} \mathrm{H}-\mathrm{NMR}$ (DMSO- $\left.d_{6}, 500 \mathrm{MHz}\right) \delta 7.40-7.41(\mathrm{~m}, 3 \mathrm{H}$, $\operatorname{ArH}), 7.58-7.60(\mathrm{~m}, 2 \mathrm{H}, \operatorname{ArH}), 7.68(\mathrm{~d}, J=8.9 \mathrm{~Hz}, 2 \mathrm{H}, \operatorname{ArH}), 8.29(\mathrm{~d}, J=8.9 \mathrm{~Hz}, 2 \mathrm{H}, \operatorname{ArH}), 9.41(\mathrm{~s}, 1 \mathrm{H}$, $\mathrm{ArH}) ;{ }^{13} \mathrm{C}\left\{{ }^{1} \mathrm{H}\right\}$ NMR (DMSO- $\left.d_{6}, 125 \mathrm{MHz}\right) \delta 107.56,123.52(2 \times \mathrm{CH}), 126.60(2 \times \mathrm{CH}), 126.64,127.77$, 127.82, $129.23(2 \times \mathrm{CH}), 130.18(2 \times \mathrm{CH}), 131.06,134.89,137.12,147.88,149.80,151.35,156.76,157.30$; FT-IR (KBr) v: 3345, 3206, 1656, 1494, 1446, 1307, 1094, $902 \mathrm{~cm}^{-1}$; MS (EI) $\mathrm{m} / z$ (relative intensity): 391 $\left(\mathrm{M}^{+}+2,36\right), 390$ (31), $389\left(\mathrm{M}^{+}, 100\right), 388$ (20), 354 (12), 304 (19), 268 (11), 111 (15), 77 (24); HRMS (EI) $\mathrm{m} / z$ : $[\mathrm{M}]^{+}$Calcd for $\mathrm{C}_{20} \mathrm{H}_{12} \mathrm{ClN}_{5} \mathrm{O}_{2}$ : 389.0680; found: 389.0687 . 
3-(4-Bromophenyl)-1-phenyl-7,8-dihydro-3H-pyrazolo[4', 3':5,6]pyrido[3,4-d]pyridazine-6,9-dione (6e), Light yellow solid; yield: 77\%;mp 337-339 ${ }^{\circ} \mathrm{C} ;{ }^{1} \mathrm{H}-\mathrm{NMR}\left(\mathrm{DMSO}-\mathrm{d}_{6}, 500 \mathrm{MHz}\right) \delta 7.40-7.41(\mathrm{~m}, 3 \mathrm{H}$, $\operatorname{ArH}), 7.59(\mathrm{~d}, J=5.5 \mathrm{~Hz}, 2 \mathrm{H}, \operatorname{ArH}), 7.82(\mathrm{~d}, J=9.0 \mathrm{~Hz}, 2 \mathrm{H}, \operatorname{ArH}), 8.25(\mathrm{~d}, J=9.0 \mathrm{~Hz}, 2 \mathrm{H}, \operatorname{ArH}), 9.42$ $(\mathrm{s}, 1 \mathrm{H}, \mathrm{ArH}) ;{ }^{13} \mathrm{C}\left\{{ }^{1} \mathrm{H}\right\} \mathrm{NMR}\left(\mathrm{DMSO}-d_{6}, 125 \mathrm{MHz}\right) \delta 107.67,119.42,123.81(2 \times \mathrm{CH}), 126.64(2 \times \mathrm{CH})$, $127.82,130.16(2 \times \mathrm{CH}+\mathrm{C}), 132.16(2 \times \mathrm{CH}+\mathrm{C}), 134.88,137.56,147.92,149.78,151.36,157.59,159.25$; FT-IR (KBr) v: 3435, 3345, 3266, 1655, 1536, 1492, 1443, 1307, 1094, 916, $902 \mathrm{~cm}^{-1}$; MS (EI) $\mathrm{m} / z$ (relative intensity): 436 (24), 435 ( $\left.\mathrm{M}^{+}+2,98\right), 434$ (39), $433\left(\mathrm{M}^{+}, 100\right), 432$ (14), 354 (11), 350 (11), 348 (12), 268 (14), 77 (26); HRMS (EI) $m / z$ : [M] ${ }^{+}$Calcd for $\mathrm{C}_{20} \mathrm{H}_{12} \mathrm{BrN}_{5} \mathrm{O}_{2}$ : 433.0174; found: 433.0171.

1-Phenyl-3-(p-tolyl)-7,8-dihydro-3H-pyrazolo[ [4' $3^{\prime}$ :5,6]pyrido[3,4-d]pyridazine-6,9-dione(6f), Light yellow solid; yield: $84 \%$; mp 346-348 ${ }^{\circ} \mathrm{C} ;{ }^{1} \mathrm{H}-\mathrm{NMR}$ (DMSO- $\left.d_{6}, 500 \mathrm{MHz}\right) \delta 2.40\left(\mathrm{~s}, 3 \mathrm{H}, \mathrm{CH}_{3}\right), 7.39-7.42(\mathrm{~m}, 5 \mathrm{H}$, $\left.\operatorname{ArH}), 7.58-7.60(\mathrm{~m}, 2 \mathrm{H}, \mathrm{ArH}), 8.07(\mathrm{~d}, J=8.4 \mathrm{~Hz}, 2 \mathrm{H}, \mathrm{ArH}), 9.39(\mathrm{~s}, 1 \mathrm{H}, \mathrm{ArH}) ;{ }^{13} \mathrm{C}^{1}{ }^{1} \mathrm{H}\right\}$ NMR (DMSO- $d_{6}$, $125 \mathrm{MHz}) \delta 20.61,106.97,118.99,122.32(2 \times \mathrm{CH}), 126.60(2 \times \mathrm{CH}), 127.68,128.86,129.60(2 \times \mathrm{CH})$, $130.21(2 \times \mathrm{CH}), 135.09,135.83,136.55,147.26,149.35,151.18,152.87,155.65 ;$ FT-IR (KBr) v: 3436, 3345, 3206, 2919, 1656, 1534, 1514, 1480, 1453, 1310, 1096, $903 \mathrm{~cm}^{-1}$; MS (EI) $\mathrm{m} / \mathrm{z}$ (relative intensity): 370 (25), $369\left(\mathrm{M}^{+}, 100\right), 368$ (16), 354 (14), 284 (18), 91 (15), 77 (19); HRMS (EI) $m / z:[\mathrm{M}]^{+}$Calcd for $\mathrm{C}_{21} \mathrm{H}_{15} \mathrm{~N}_{5} \mathrm{O}_{2}$ : 369.1226; found: 369.1216 .

3-(4-Methoxyphenyl)-1-phenyl-7,8-dihydro-3H-pyrazolo[4' ,3' $\left.^{\prime} 5,6\right]$ pyrido[3,4-d]pyridazine-6,9-dione (6g), Deep yellow solid; yield: $81 \%$; mp $311-313{ }^{\circ} \mathrm{C} ;{ }^{1} \mathrm{H}-\mathrm{NMR}\left(\mathrm{DMSO}-\mathrm{d}_{6}, 500 \mathrm{MHz}\right) \delta 3.85\left(\mathrm{~s}, 3 \mathrm{H}, \mathrm{OCH}_{3}\right)$, $7.17(\mathrm{~d}, J=11.2 \mathrm{~Hz}, 2 \mathrm{H}, \operatorname{ArH}), 7.43(\mathrm{~s}, 3 \mathrm{H}, \operatorname{ArH}), 7.58-7.60(\mathrm{~m}, 2 \mathrm{H}, \operatorname{ArH}), 8.03(\mathrm{~d}, J=11.2 \mathrm{~Hz}, 2 \mathrm{H}, \operatorname{Ar} H)$, $9.38(\mathrm{~s}, 1 \mathrm{H}, \mathrm{ArH}) ;{ }^{13} \mathrm{C}\left\{{ }^{1} \mathrm{H}\right\}$ NMR (DMSO- $\left.d_{6}, 125 \mathrm{MHz}\right) \delta 55.49,106.64,114.38(2 \times \mathrm{CH}), 115.59,124.31$ $(2 \times \mathrm{CH}), 124.60,126.71(2 \times \mathrm{CH}), 127.77,130.23(2 \times \mathrm{CH}), 131.18,135.03,147.01,149.17,151.12,152.63$, 156.80, 158.33; FT-IR (KBr) v: 3435, 3226, 3065, 2886, 1650, 1590, 1535, 1516, 1441, 1362, 1252, 1170, $905 \mathrm{~cm}^{-1}$; MS (EI) $\mathrm{m} / z$ (relative intensity): 386 (24), $385\left(\mathrm{M}^{+}, 100\right), 370$ (13), 77 (18); HRMS (EI) $\mathrm{m} / z$ : $[\mathrm{M}]^{+}$Calcd for $\mathrm{C}_{21} \mathrm{H}_{15} \mathrm{~N}_{5} \mathrm{O}_{3}$ : 385.1175; found: 385.1180 .

3-(4-Cyanophenyl)-1-phenyl-7,8-dihydro-3H-pyrazolo[4',3':5,6]pyrido[3,4-d]pyridazine-6,9-dione (6h), Yellow solid; yield: 73\%; mp 344-347 ${ }^{\circ} \mathrm{C} ;{ }^{1} \mathrm{H}-\mathrm{NMR}$ (DMSO- $\left.d_{6}, 500 \mathrm{MHz}\right) \delta 7.43-7.44(\mathrm{~m}, 3 \mathrm{H}, \mathrm{ArH})$, 7.60-7.61 (m, 2H, ArH), $8.08(\mathrm{~d}, J=6.6 \mathrm{~Hz}, 2 \mathrm{H}, \mathrm{ArH}), 8.56(\mathrm{~d}, J=6.6 \mathrm{~Hz}, 2 \mathrm{H}, \mathrm{ArH}), 9.45(\mathrm{~s}, 1 \mathrm{H}, \mathrm{ArH})$; ${ }^{13} \mathrm{C}\left\{{ }^{1} \mathrm{H}\right\}$ NMR (DMSO- $\left.d_{6}, 125 \mathrm{MHz}\right) \delta 108.84,118.51,121.39,121.70(2 \times \mathrm{CH}), 126.74(2 \times \mathrm{CH}), 128.07$, 128.63, $130.08(2 \times \mathrm{CH}), 130.15,133.62(2 \times \mathrm{CH}), 134.51,141.67,148.75,149.75,151.87,155.15,156.71$; FT-IR (KBr) v: 3397, 3284, 3056, 2228, 1606, 1569, 1516, 1430, 1400, 1317, $905 \mathrm{~cm}^{-1}$; MS (EI) m/z (relative intensity): 381 (26), 380 (M+1 $(100), 379$ (23), 295 (17), 102 (13), 77(29); HRMS (EI) $m / z:[\mathrm{M}]^{+}$Calcd for $\mathrm{C}_{21} \mathrm{H}_{12} \mathrm{~N}_{6} \mathrm{O}_{2}$ : 380.1022; found: 380.1030 .

3-(4-Nitrophenyl)-1-phenyl-7,8-dihydro-3H-pyrazolo[4' $\left.{ }^{\prime}, 3^{\prime}: 5,6\right]$ pyrido[3,4-d]pyridazine-6,9-dione (6i), Yellow solid; yield: $69 \%$; mp 340-342 ${ }^{\circ} \mathrm{C} ;{ }^{1} \mathrm{H}-\mathrm{NMR}$ (DMSO- $\left.d_{6}, 500 \mathrm{MHz}\right) \delta 7.41-7.44(\mathrm{~m}, 3 \mathrm{H}, \mathrm{ArH})$, $7.61(\mathrm{~d}, J=6.3 \mathrm{~Hz}, 2 \mathrm{H}, \operatorname{ArH}), 8.48(\mathrm{~d}, J=8.3 \mathrm{~Hz}, 2 \mathrm{H}, \operatorname{ArH}), 8.67(\mathrm{~d}, J=8.3 \mathrm{~Hz}, 2 \mathrm{H}, \operatorname{ArH}), 9.47(\mathrm{~s}, 1 \mathrm{H}$, $\mathrm{ArH}), 12.11(\mathrm{br}, 1 \mathrm{H}, \mathrm{NH}) ;{ }^{13} \mathrm{C}\left\{{ }^{1} \mathrm{H}\right\} \mathrm{NMR}\left(\mathrm{DMSO}-d_{6}, 125 \mathrm{MHz}\right) \delta 113.65,121.61(2 \times \mathrm{CH}), 124.52,125.13$ $(2 \times \mathrm{CH}), 126.85(2 \times \mathrm{CH}), 128.22,130.12(2 \times \mathrm{CH}), 130.27,134.47,143.27,145.04,149.17,149.92,152.09$, 154.07, 158.18; FT-IR (KBr) v: 3435, 1637, 1596, 1522, 1341, 1112, $905 \mathrm{~cm}^{-1}$; MS (EI) $\mathrm{m} / z$ (relative intensity): 401 (23), $400\left(\mathrm{M}^{+}, 100\right), 370$ (22), 315 (11), 77(19); HRMS (EI) $\mathrm{m} / \mathrm{z}$ : [M] ${ }^{+}$Calcd for For $\mathrm{C}_{20} \mathrm{H}_{12} \mathrm{~N}_{6} \mathrm{O}_{4}$ : 400.0920; found: 400.0919 .

3-(3-Chlorophenyl)-7,8-dihydro-3H-pyrazolo[4', 3':5,6]pyrido[3,4-d]pyridazine-6,9-dione(6j), Light yellow solid; yield: $71 \%$; mp 351-352 ${ }^{\circ} \mathrm{C} ;{ }^{1} \mathrm{H}-\mathrm{NMR}$ (DMSO- $\left.d_{6}, 500 \mathrm{MHz}\right) \delta 7.51(\mathrm{~d}, J=8.03 \mathrm{~Hz}, 1 \mathrm{H}, \mathrm{ArH}), 7.66$ $(\mathrm{t}, J=8.0 \mathrm{~Hz}, 1 \mathrm{H}, \operatorname{Ar} H), 8.28(\mathrm{~d}, J=8.0 \mathrm{~Hz}, 1 \mathrm{H}, \operatorname{ArH}), 8.39(\mathrm{~s}, 1 \mathrm{H}, \operatorname{ArH}), 8.88(\mathrm{~s}, 1 \mathrm{H}, \operatorname{ArH}), 9.40(\mathrm{~s}, 1 \mathrm{H}$, $\mathrm{ArH}), 10.20$ (br, $\left.1 \mathrm{H}, \mathrm{NH}) ;{ }^{13} \mathrm{C}_{\{1}{ }^{1} \mathrm{H}\right\}$ NMR (DMSO- $\left.d_{6}, 125 \mathrm{MHz}\right) \delta 109.53,119.80,120.84,126.68(2 \times \mathrm{C})$, $131.14(\mathrm{CH}+\mathrm{C}), 133.57,136.04,139.62,149.36,150.78,152.47,155.87$; FT-IR (KBr) v: 3433, 3294, 3168, 2974, 1639, 1594, 1568, 1487, 1448, 1274, 1218, $1125 \mathrm{~cm}^{-1}$; MS (EI) $\mathrm{m} / \mathrm{z}$ (relative intensity): $315\left(\mathrm{M}^{+}+2,35\right)$, 
314 (28), $313\left(\mathrm{M}^{+}, 100\right), 278$ (12), 255 (13), 227 (21), 111(12), 75 (11); HRMS (EI) m/z: [M] ${ }^{+}$Calcd for $\mathrm{C}_{14} \mathrm{H}_{8} \mathrm{ClN}_{5} \mathrm{O}_{2}$ : 313.0367; found: 313.0367 .

\subsection{Standard Procedure for Synthesis of N-Aminopyrazolopyrrolopyridine Diones (7a-i)}

The reliable procedure involved the treatment of 1,3-diarylpyrazolopyrrolopyridine-6,8-diones (11a-i, 1.0 equiv.) with hydrazine monohydrate $\left(\sim 5.0\right.$ equiv.) in $\mathrm{EtOH} / \mathrm{H}_{2} \mathrm{O}(2.0 \mathrm{~mL} / 2.0 \mathrm{~mL})$ in ice-bath to room temperature within $48 \mathrm{~h}$. When the reaction was completed, the reaction mixture was added to water $(10 \mathrm{~mL})$ for precipitation. The precipitate was filtered, washed with cold water $(10 \mathrm{~mL})$ and $n$-hexane/EA $(1 / 2,15 \mathrm{~mL})$ to give the corresponding crude $N$-aminophthalimides $7 \mathbf{a}-\mathbf{i}$. The crude desired products $7 \mathbf{a}-\mathbf{i}$ were recrystallized in acetone/THF (1/4) solution to obtain the pure $\mathrm{N}$-aminophthalimides $\mathbf{7 a - i}$ in $71-87 \%$ yields [31,32].

7-Amino-1,3-diphenylpyrazolo[3,4-b]pyrrolo[3,4-d]pyridine-6,8-(3H,7H)-dione (7a), White solid; yield: $83 \%$; mp 217-219 ${ }^{\circ} \mathrm{C} ;{ }^{1} \mathrm{H}-\mathrm{NMR}$ (DMSO- $\left.d_{6}, 400 \mathrm{MHz}\right) \delta 4.55\left(\mathrm{br}, 2 \mathrm{H}, \mathrm{NH}_{2}\right), 7.42(\mathrm{t}, J=7.5 \mathrm{~Hz}, 1 \mathrm{H}, \mathrm{ArH})$, 7.49-7.55 (m, 3H, ArH), 7.60-7.65 (m, 4H, ArH), $8.25(\mathrm{~d}, J=8.1 \mathrm{~Hz}, 2 \mathrm{H}, \operatorname{ArH}), 8.82(\mathrm{~s}, 1 \mathrm{H}, \operatorname{ArH}) ;{ }^{13} \mathrm{C}\left\{{ }^{1} \mathrm{H}\right\}$ NMR (DMSO- $\left.d_{6}, 100 \mathrm{MHz}\right) \delta 111.65,121.43(2 \times \mathrm{CH}), 123.37,126.80,128.27(2 \times \mathrm{CH}), 128.58(2 \times \mathrm{CH})$, 128.96, $129.41(2 \times \mathrm{CH}), 132.04,138.44,139.23,146.02,148.82,150.61,164.18,164.49$; FT-IR (KBr) v: 3275, 3208, 3172, 3035, 1633.0, 1572, 1518.7, $1501 \mathrm{~cm}^{-1}$; MS (EI) $\mathrm{m} / \mathrm{z}$ (relative intensity): 356 (20), $355\left(\mathrm{M}^{+}, 100\right)$, 354 (18), 270 (13), 77.0(18); HRMS (EI) $m / z$ : [M] ${ }^{+}$Calcd for $\mathrm{C}_{20} \mathrm{H}_{13} \mathrm{~N}_{5} \mathrm{O}_{2}$ : 355.1069; found: 355.1060.

7-Amino-3-(2-chlorophenyl)-1-phenylpyrazolo[3,4-b]pyrrolo[3,4-d]pyridine-6,8-(3H,7H)-dione (7b), Yellow solid; yield: 71\%; mp 165-166 ${ }^{\circ} \mathrm{C} ;{ }^{1} \mathrm{H}-\mathrm{NMR}$ (DMSO- $\left.d_{6}, 500 \mathrm{MHz}\right) \delta 4.52$ (br, 2H, NH $\left.\mathrm{N}_{2}\right), 7.48$ (d, $J=7.0 \mathrm{~Hz}, 1 \mathrm{H}, \mathrm{ArH}), 7.52(\mathrm{~d}, J=7.1 \mathrm{~Hz}, 2 \mathrm{H}, \mathrm{ArH}), 7.60-7.68(\mathrm{~m}, 4 \mathrm{H}, \mathrm{ArH}), 7.74(\mathrm{~d}, J=7.7 \mathrm{~Hz}, 1 \mathrm{H}$, $\operatorname{ArH}), 7.79(\mathrm{~d}, J=7.7 \mathrm{~Hz}, 1 \mathrm{H}, \operatorname{ArH}), 8.71(\mathrm{~s}, 1 \mathrm{H}, \operatorname{ArH}) ;{ }^{13} \mathrm{C}\left\{{ }^{1} \mathrm{H}\right\} \mathrm{NMR}\left(\mathrm{DMSO}-d_{6}, 125 \mathrm{MHz}\right) \delta 108.50$, 122.16, 122.88, 123.33, $127.72(2 \times \mathrm{CH}), 129.27(3 \times \mathrm{CH}), 129.72(2 \times \mathrm{CH}), 131.26,131.46,136.60,136.98$, 143.86, 145.72, 153.20, 166.81, 168.47; FT-IR (KBr) v: 3337, 3296, 2952, 2920, 1778, 1740, 1498, 1375, 1315, $1014 \mathrm{~cm}^{-1}$; MS (EI) $\mathrm{m} / z$ (relative intensity): $391\left(\mathrm{M}^{+}+2,32\right), 390(22), 389\left(\mathrm{M}^{+}, 100\right), 355$ (18), 354 (90), 304 (12), 268 (11), 77 (18); HRMS (EI) $m / z$ : [M] ${ }^{+}$Calcd for $\mathrm{C}_{20} \mathrm{H}_{12} \mathrm{ClN}_{5} \mathrm{O}_{2}$ : 389.0680; found: 389.0672.

7-Amino-3-(3-chlorophenyl)-1-phenylpyrazolo[3,4-b]pyrrolo[3,4-d]pyridine-6,8-(3H,7H)-dione (7c), Yellow solid; yield: 73\%; mp 173-175 ${ }^{\circ} \mathrm{C} ;{ }^{1} \mathrm{H}-\mathrm{NMR}$ (DMSO- $\left.d_{6}, 400 \mathrm{MHz}\right) \delta 4.55$ (br, 2H, NH $\mathrm{N}_{2}$ ), 7.47-7.54 (m, 4H, ArH), 7.64-7.67 (m, 3H, ArH), $8.31(\mathrm{~d}, J=8.9 \mathrm{~Hz}, 1 \mathrm{H}, \operatorname{ArH}), 8.42(\mathrm{~s}, 1 \mathrm{H}, \mathrm{ArH}), 8.86(\mathrm{~s}, 1 \mathrm{H}, \operatorname{ArH})$; ${ }^{13} \mathrm{C}\left\{{ }^{1} \mathrm{H}\right\}$ NMR (DMSO- $\left.d_{6}, 100 \mathrm{MHz}\right) \delta 112.05,119.33,120.34,123.72,126.32,128.28(2 \times \mathrm{CH}), 128.57$ $(2 \times \mathrm{CH}), 129.11,131.21,131.73,133.65,139.41,139.64,146.61,148.98,150.72,163.96,164.33$; FT-IR (KBr) $v: 3264,3168,3034,1649,1614,1595,1488,1431,1300,803 \mathrm{~cm}^{-1}$; MS (EI) $\mathrm{m} / \mathrm{z}$ (relative intensity): $391\left(\mathrm{M}^{+}+2,33\right), 390(24), 389\left(\mathrm{M}^{+}, 100\right), 374$ (13), 304 (11), 77 (14); HRMS (EI) $m / z:[\mathrm{M}]^{+}$Calcd for $\mathrm{C}_{20} \mathrm{H}_{12} \mathrm{ClN}_{5} \mathrm{O}_{2}$ : 389.0680; found: 389.0688 .

7-Amino-3-(4-chlorophenyl)-1-phenylpyrazolo[3,4-b]pyrrolo[3,4-d]pyridine-6,8-(3H,7H)-dione (7d), Light yellow solid; yield: $81 \%$; mp $226-227{ }^{\circ} \mathrm{C} ;{ }^{1} \mathrm{H}-\mathrm{NMR}$ (DMSO- $\left.d_{6}, 500 \mathrm{MHz}\right) \delta 4.55\left(\mathrm{br}, 2 \mathrm{H}, \mathrm{NH}_{2}\right.$ ), 7.48-7.55 (m, 3H, ArH), $7.64(\mathrm{~d}, J=7.6 \mathrm{~Hz}, 2 \mathrm{H}, \operatorname{ArH}), 7.69(\mathrm{~d}, J=8.4 \mathrm{~Hz}, 2 \mathrm{H}, \operatorname{ArH}), 8.35(\mathrm{~d}, J=8.4 \mathrm{~Hz}$, 2H, ArH), $\left.8.84(\mathrm{~s}, 1 \mathrm{H}, \mathrm{ArH}) ;{ }^{13} \mathrm{C}^{1}{ }^{1} \mathrm{H}\right\} \mathrm{NMR}$ (DMSO-d $\left.6,125 \mathrm{MHz}\right) \delta 111.85,122.54(2 \times \mathrm{CH}), 123.55$, $128.24(2 \times \mathrm{CH}), 128.53(2 \times \mathrm{CH}), 129.03,129.36(2 \times \mathrm{CH}), 130.67,131.81,137.31,139.34,146.35,148.88$, 150.57, 163.99, 164.34; FT-IR (KBr) v: 3275, 3207, 3170, 1633, 1499, $828 \mathrm{~cm}^{-1}$; MS (EI) $\mathrm{m} / \mathrm{z}$ (relative intensity): $391\left(\mathrm{M}^{+}+2,34\right), 390$ (28), $389\left(\mathrm{M}^{+}, 100\right), 388$ (15), 304 (12), 77 (13); HRMS (EI) m/z: [M] ${ }^{+}$ Calcd for $\mathrm{C}_{20} \mathrm{H}_{12} \mathrm{ClN}_{5} \mathrm{O}_{2}$ : 389.0680; found: 389.0686 .

7-Amino-3-(4-bromophenyl)-1-phenylpyrazolo[3,4-b]pyrrolo[3,4-d]pyridine-6,8-(3H,7H)-dione (7e), Yellow solid; yield: 79\%; mp 235-239 ${ }^{\circ} \mathrm{C}$; ${ }^{1} \mathrm{H}-\mathrm{NMR}$ (DMSO- $\left.d_{6}, 500 \mathrm{MHz}\right) \delta 4.55$ (br, $2 \mathrm{H}, \mathrm{NH}_{2}$ ), 7.49-7.55 $(\mathrm{m}, 3 \mathrm{H}, \mathrm{ArH}), 7.64(\mathrm{~d}, J=6.9 \mathrm{~Hz}, 2 \mathrm{H}, \mathrm{ArH}), 7.82(\mathrm{~d}, J=8.7 \mathrm{~Hz}, 2 \mathrm{H}, \mathrm{ArH}), 8.29(\mathrm{~d}, J=8.7 \mathrm{~Hz}, 2 \mathrm{H}, \mathrm{ArH})$, $8.84(\mathrm{~s}, 1 \mathrm{H}, \mathrm{ArH}) ;{ }^{13} \mathrm{C}\left\{{ }^{1} \mathrm{H}\right\}$ NMR (DMSO- $\left.d_{6}, 125 \mathrm{MHz}\right) \delta 111.91,118.95,122.81(2 \times \mathrm{CH}), 123.55,128.25$ 
$(2 \times \mathrm{CH}), 128.54(2 \times \mathrm{CH}), 129.04,131.80,132.28(2 \times \mathrm{CH}), 137.75,139.33,146.40,148.90,150.59,164.00$, 164.35; FT-IR (KBr) v: 3275, 3208, 3170, 3071, 3037, 1632, 1495, $826 \mathrm{~cm}^{-1}$; MS (EI) $\mathrm{m} / \mathrm{z}$ (relative intensity): 436 (22), $435\left(\mathrm{M}^{+}+2,100\right), 354$ (33), $433\left(\mathrm{M}^{+}, 99\right), 432$ (12), 420 (19), 419 (11), 418 (19), 354 (11), 350 (10), 348 (11), 268 (17), 77 (26); HRMS (EI) $m / z$ : [M] ${ }^{+}$Calcd for $\mathrm{C}_{20} \mathrm{H}_{12} \mathrm{BrN}_{5} \mathrm{O}_{2}$ : 433.0174; found: 433.0171.

7-Amino-1-phenyl-3-(p-tolyl)pyrazolo[3,4-b]pyrrolo[3,4-d]pyridine-6,8-(3H,7H)-dione (7f), Yellow solid; yield: $86 \%$; mp 232-233 ${ }^{\circ} \mathrm{C}$; ${ }^{1} \mathrm{H}-\mathrm{NMR}$ (DMSO- $\left.d_{6}, 500 \mathrm{MHz}\right) \delta 2.40\left(\mathrm{~s}, 3 \mathrm{H}, \mathrm{CH}_{3}\right.$ ), $4.55\left(\mathrm{br}, 2 \mathrm{H}, \mathrm{NH}_{2}\right.$ ), 7.42 $(\mathrm{d}, J=8.0 \mathrm{~Hz}, 2 \mathrm{H}, \operatorname{ArH}), 7.49(\mathrm{~d}, J=7.3 \mathrm{~Hz}, 1 \mathrm{H}, \operatorname{ArH}), 7.52(\mathrm{t}, J=7.3 \mathrm{~Hz}, 2 \mathrm{H}, \operatorname{ArH}), 7.64(\mathrm{~d}, J=7.3$ $\mathrm{Hz}, 2 \mathrm{H}, \operatorname{ArH}), 8.12(\mathrm{~d}, J=8.0 \mathrm{~Hz}, 2 \mathrm{H} \mathrm{ArH}), 8.81(\mathrm{~s}, 1 \mathrm{H}, \operatorname{Ar} H) ;{ }^{13} \mathrm{C}\left\{{ }^{1} \mathrm{H}\right\}$ NMR (DMSO- $d_{6}, 125 \mathrm{MHz}$ ) $\delta 20.63,111.44,121.35(2 \times \mathrm{CH}), 123.18,128.21(2 \times \mathrm{CH}), 128.54(2 \times \mathrm{CH}), 128.85,129.73(2 \times \mathrm{CH}), 132.09$, 136.06, 136.18, 139.13, 145.69, 148.72, 150.44, 164.20, 164.50; FT-IR (KBr) v: 3276, 3209, 3171, 3032, 1634, $1517 \mathrm{~cm}^{-1}$; MS (EI) $\mathrm{m} / \mathrm{z}$ (relative intensity): 370 (25), $369\left(\mathrm{M}^{+}, 100\right), 368$ (13), 354 (21), 284 (12), 207 (10), 91.1(11), 77.1(13); HRMS (EI) $m / z$ : [M] ${ }^{+}$Calcd for $\mathrm{C}_{21} \mathrm{H}_{15} \mathrm{~N}_{5} \mathrm{O}_{2}$ : 369.1226; found: 369.1231 .

7-Amino-3-(4-methoxyphenyl)-1-phenylpyrazolo[3,4-b]pyrrolo[3,4-d]pyridine-6,8-(3H,7H)-dione (7g), Yellow solid; yield: $87 \%$; mp 331-332 ${ }^{\circ} \mathrm{C} ;{ }^{1} \mathrm{H}-\mathrm{NMR}$ (DMSO- $\left.d_{6}, 500 \mathrm{MHz}\right) \delta 3.83\left(\mathrm{~s}, 3 \mathrm{H}, \mathrm{OCH}_{3}\right), 4.53$ (br, $\left.2 \mathrm{H}, \mathrm{NH}_{2}\right), 7.17(\mathrm{~d}, J=8.7 \mathrm{~Hz}, 2 \mathrm{H}, \mathrm{ArH}), 7.48-7.53(\mathrm{~m}, 3 \mathrm{H}, \operatorname{ArH}), 7.62(\mathrm{~d}, J=7.1 \mathrm{~Hz}, 2 \mathrm{H}, \mathrm{ArH}), 8.06(\mathrm{~d}$, $J=8.7 \mathrm{~Hz}, 2 \mathrm{H}, \mathrm{ArH}), 8.78(\mathrm{~s}, 1 \mathrm{H}, \mathrm{ArH}) ;{ }^{13} \mathrm{C}\left\{{ }^{1} \mathrm{H}\right\} \mathrm{NMR}\left(\mathrm{DMSO}_{-} d_{6}, 125 \mathrm{MHz}\right) \delta 55.64,111.24,114.62$ $(2 \times \mathrm{CH}), 123.14,123.51(2 \times \mathrm{CH}), 128.37(2 \times \mathrm{CH}), 128.65(2 \times \mathrm{CH}), 128.97,131.60,132.25,139.14,145.54$, 148.83, 150.44, 158.16, 164.43, 164.73; FT-IR (KBr) v: 3215, 3066, 3004, 2963, 2935, 2837, 1639, 1577, 1516, 1462, 1443, $1252 \mathrm{~cm}^{-1}$; MS (EI) $\mathrm{m} / z$ (relative intensity): 386 (21), $385\left(\mathrm{M}^{+}, 100\right), 370$ (14), 77.0(10); HRMS (EI) $m / z:[\mathrm{M}]^{+}$Calcd for $\mathrm{C}_{21} \mathrm{H}_{15} \mathrm{~N}_{5} \mathrm{O}_{3}: 385.1175$; found: 385.1182 .

7-Amino-3-(4-cyanophenyl)-1-phenylpyrazolo[3,4-b]pyrrolo[3,4-d]pyridine-6,8-(3H,7H)-dione (7h), Yellow solid; yield: 73\%; mp 333-335 ${ }^{\circ} \mathrm{C} ;{ }^{1} \mathrm{H}-\mathrm{NMR}$ (DMSO- $\left.d_{6}, 500 \mathrm{MHz}\right) \delta 4.55\left(\mathrm{br}, 2 \mathrm{H}, \mathrm{NH}_{2}\right.$ ), 7.50-7.55 $(\mathrm{m}, 3 \mathrm{H}, \operatorname{ArH}), 7.65(\mathrm{~d}, J=7.1 \mathrm{~Hz}, 2 \mathrm{H}, \operatorname{ArH}), 8.09(\mathrm{~d}, J=8.5 \mathrm{~Hz}, 2 \mathrm{H}, \operatorname{ArH}), 8.61(\mathrm{~d}, J=8.5 \mathrm{~Hz}, 2 \mathrm{H}, \operatorname{Ar} H)$, $8.87(\mathrm{~s}, 1 \mathrm{H}, \mathrm{ArH}) ;{ }^{13} \mathrm{C}\left\{{ }^{1} \mathrm{H}\right\}$ NMR (DMSO- $\left.d_{6}, 125 \mathrm{MHz}\right) \delta 108.41,112.58,118.68,120.75(2 \times \mathrm{CH}), 124.12$, $128.35(2 \times \mathrm{CH}), 128.59(2 \times \mathrm{CH}), 129.33,131.55,133.84(2 \times \mathrm{CH}), 139.53,141.99,147.47,149.11,151.12$, 163.83, 164.27; FT-IR (KBr) v: 3330, 3274, 2227, 1665, 1635, 1607, 1518, 1409, 1255, $844 \mathrm{~cm}^{-1}$; MS (EI) $\mathrm{m} / \mathrm{z}$ (relative intensity): 381 (22), $380\left(\mathrm{M}^{+}, 100\right), 379$ (18), 295 (13), 77(14); HRMS (EI) $\mathrm{m} / z$ : $[\mathrm{M}]^{+}$Calcd for $\mathrm{C}_{21} \mathrm{H}_{12} \mathrm{~N}_{6} \mathrm{O}_{2}$ : 380.1022; found: 380.1023 .

7-Amino-3-(4-nitrophenyl)-1-phenylpyrazolo[3,4-b]pyrrolo[3,4-d]pyridine-6,8-(3H,7H)-dione (7i), Yellow solid; yield: 74\%; mp 281-282 ${ }^{\circ} \mathrm{C}$; ${ }^{1} \mathrm{H}-\mathrm{NMR}$ (DMSO- $\left.d_{6}, 500 \mathrm{MHz}\right) \delta 7.53-7.57(\mathrm{~m}, 3 \mathrm{H}, \mathrm{ArH}), 7.93(\mathrm{~d}$, $J=6.5 \mathrm{~Hz}, 2 \mathrm{H}, \operatorname{Ar} H), 8.48(\mathrm{~d}, J=9.2 \mathrm{~Hz}, 2 \mathrm{H}, \operatorname{ArH}), 8.67(\mathrm{~d}, J=9.2 \mathrm{~Hz}, 2 \mathrm{H}, \operatorname{ArH}), 9.19(\mathrm{~s}, 1 \mathrm{H}, \operatorname{Ar} H)$; ${ }^{13} \mathrm{C}\left\{{ }^{1} \mathrm{H}\right\}$ NMR (DMSO- $\left.d_{6}, 125 \mathrm{MHz}\right) \delta 109.57,121.41(2 \times \mathrm{CH}), 123.52,125.21(2 \times \mathrm{CH}), 127.91(2 \times \mathrm{CH})$, $129.73,129.90(2 \times \mathrm{CH}), 131.21,136.89,143.24,144.26,145.12,147.11,153.90,166.71,168.43$; FT-IR (KBr) v: 3190, 3120, 3064, 1595, 1500, 1341, 1112, $857 \mathrm{~cm}^{-1}$; MS (EI) $\mathrm{m} / \mathrm{z}$ (relative intensity): $400\left(\mathrm{M}^{+}, 4\right), 386$ (26), 385 (100), 338 (13), 236 (10), 77 (13); HRMS (EI) m/z: [M] ${ }^{+}$Calcd for $\mathrm{C}_{20} \mathrm{H}_{12} \mathrm{~N}_{6} \mathrm{O}_{4}$ : 400.0920; found: 400.0925 .

\subsection{Determination of the Fluorescence Quantum Yield}

The fluorescence quantum yield $\Phi_{\mathrm{x}}$ was determined through the comparative method. The quinine sulfate $\left(\Phi_{\mathrm{st}}=0.60, \lambda_{\mathrm{ex}}=350 \mathrm{~nm}\right)$ in $\mathrm{H}_{2} \mathrm{SO}_{4} 0.05 \mathrm{M}$ was used as the standard, and it was calculated by following equation [48]:

$$
\Phi_{\mathrm{x}} / \Phi_{\mathrm{st}}=\left[\mathrm{A}_{\mathrm{st}} / \mathrm{A}_{\mathrm{x}}\right]\left[\mathrm{n}_{\mathrm{x}}{ }^{2} / \mathrm{n}_{\mathrm{st}}{ }^{2}\right]\left[\mathrm{D}_{\mathrm{x}} / \mathrm{D}_{\mathrm{st}}\right],
$$

where st: standard; $x$ : sample; $\Phi:$ quantum yield; A: absorbance at the excitation wavelength; D: area under the fluorescence spectra on an energy scale; $n$ : the refractive index of the solution. In the process of detection, the absorbance should be controlled and lower than 0.1 . 


\section{Conclusions}

Pyrazolopyridopyridazine diones 6 and $N$-aminopyrazolopyrrolopyridine diones 7 can be prepared in three synthesis methods from 1,3-diarylpyrazolopyrrolopyridine-6,8-diones, 1,3-diaryl7-methylpyrazolopyrrolopyridine-6,8-diones, or 1,3-diarylfuropyrazolopyridine-6,8-diones with hydrazine monohydrate. Based on the experimental results, 1,3-diarylpyrazolopyrrolopyridine-6, 8 -diones were conceived as the best reactive starting materials. Furthermore, compounds 6 and 7 were also selectively synthesized under kinetic and thermodynamic control reactions. For the further photoluminescence, solvatofluorism, and quantum yield $\left(\Phi_{\mathrm{f}}\right)$ studies, pyrazolopyridopyridazine diones 6 generally exhibited the stronger fluorescence intensity and possessed the significant substituent effect, particularly for $\mathbf{6 c}$ with a $m$-chloro group. On the other hand, the best $\Phi_{\mathrm{f}}$ value of $\mathbf{6} \mathbf{j}$ was obtained $\left(\Phi_{\mathrm{f}}=0.140\right)$ and similar to luminol $\left(\mathbf{1}, \Phi_{\mathrm{f}}=0.175\right)$, possibly caused by the planar skeletal conformation. Based on the above photoluminescence studies, we also found that the efficient introduction of the pyrazole and pyridine chromophores led to an increase in the conjugation and aromaticity of compounds 6 and 7 when compared with the standard luminol.

Supplementary Materials: The following are available online, copies of ${ }^{1} \mathrm{H}$ and ${ }^{13} \mathrm{C}-\mathrm{NMR}$ spectra of compounds $6 \mathbf{a}-6 \mathbf{j}$ and $7 \mathbf{a}-7 \mathbf{i}$.

Author Contributions: F.F.W. conceived and designed the experiments; C.-C.T., C.-Y.C., and S.-E.T. performed the experiments; H.T., N.U., C.-Y.L., C.C.T., C.-Y.C., and S.-E.T. analyzed the data; F.F.W., H.T., N.U., C.-Y.L., contributed reagents/materials/analysis tools; F.F.W., C.-Y.L., C.C.T., and S.-E.T. wrote the paper. All authors have read and agreed to the published version of the manuscript.

Funding: This research was funded by the Tsuzuki Institute for Traditional Medicine and the China Medical University, Taiwan (CMU108-N-04)

Acknowledgments: We are grateful to the Tsuzuki Institute for Traditional Medicine and the China Medical University, Taiwan (CMU108-N-04) for financial support.

Conflicts of Interest: The authors declare no conflicts of interest.

\section{References}

1. Boivin, D.B.; Tremblay, G.M.; James, F.O. Working on Atypical Schedules. Sleep Med. 2007, 8, 578-589. [CrossRef] [PubMed]

2. Menegatti, R.; Silva, G.M.; Zapata-Sudo, G.; Raimundo, J.M.; Sudo, R.T.; Barreiro, E.J.; Fraga, C.A.M. Design, Synthesis, and Pharmacological Evaluation of New Neuroactive Pyrazolo[3,4-b]pyrrolo[3,4-d]pyridine Derivatives with in vivo Hypnotic and Analgesic Profile. Bioorg. Med. Chem. 2006, 14, 632-640. [CrossRef] [PubMed]

3. Nascimento-Junior, N.M.; Mendes, T.C.F.; Leal, D.M.; Correa, C.M.N.; Sudo, R.T.; Zapata-Sudo, G.; Barreiro, E.J.; Fraga, C.A.M. Microwave-assisted Synthesis and Structure-activity Relationships of Neuroactive pyrazolo[3,4-b]pyrrolo[3,4-d]pyridine Derivatives. Bioorg. Med. Chem. Lett. 2010, 20, 74-77. [CrossRef] [PubMed]

4. Yu, G.; Macor, J.E.; Chung, H.-J.; Humora, M.; Katipally, K.; Wang, Y.; Kim, S. Fused Pyridopyridazine Inhibitors of cGMP Phosphodiesterase. U.S. Patent No. 6,316,438, 13 November 2001.

5. Yu, G.; Mason, H.; Wu, X.; Wang, J.; Chong, S.; Beyer, B.; Henwood, A.; Pongrac, R.; Seliger, L.; He, B.; et al. Substituted Pyrazolopyridopyridazines as Orally Bioavailable Potent and Selective PDE5 Inhibitors: Potential Agents for Treatment of Erectile Dysfunction. J. Med. Chem. 2003, 46, 457-460. [CrossRef] [PubMed]

6. Li, Y.; Zhu, H.; Trush, M.A. Detection of Mitochondria-derived Reactive Oxygen Species Production by the Chemilumigenic Probes Lucigenin and Luminol. Biochim. Biophys. Acta 1999, 1428, 1-12. [CrossRef]

7. García-Campaña, A.M.; Baeyens, W.R.G. Chemiluminescence in Chemical Analysis; Marcel Dekker: New York, NY, USA, 2001.

8. Roda, A. Chemiluminescence and Bioluminescence: Past, Present, and Future; RSC: Cambridge, UK, 2011.

9. Barni, F.; Lewis, S.W.; Berti, A.; Miskelly, G.M.; Lago, G. Forensic Application of the Luminol Reaction as a Presumptive Test for Latent Blood Detection. Talanta 2007, 72, 896-913. [CrossRef] 
10. Zhou, H.; Yue, H.; Zhou, Y.; Wang, L.; Fu, Z. A Novel Disposable Immunosensor based on Quenching of Electrochemiluminescence Emission of $\mathrm{Ru}(\mathrm{bpy})_{3}{ }^{2+}$ by Amorphous Carbon Nanoparticles. Sens. Actuators $B$ 2015, 209, 744-750. [CrossRef]

11. Yoshida, H.; Ureshino, K.; Ishida, J.; Nohta, H.; Yamaguchi, M. Chemiluminescent Properties of some Luminol related Compounds (II). Dyes Pigm. 1999, 41, 177-182. [CrossRef]

12. Gu, W.; Deng, X.; Gu, X.; Jia, X.; Lou, B.; Zhang, X.; Li, J.; Wang, E. Stabilized, Superparamagnetic Functionalized Graphene/ $\mathrm{Fe}_{3} \mathrm{O}_{4} @ \mathrm{Au}$ Nanocomposites for a Magnetically-controlled Solid-state Electrochemiluminescence. Biosensing Application. Anal. Chem. 2015, 87, 1876-1881. [CrossRef]

13. Wang, Y.-Z.; Hao, N.; Feng, Q.-M.; Shi, H.-W.; Xu, J.-J.; Chen, H.-Y. A Ratiometric Electrochemiluminescence Detection for Cancer Cells using $\mathrm{g}-\mathrm{C}_{3} \mathrm{~N}_{4}$ Nanosheets and Ag-PAMAM-luminol nanocomposites. Biosens. Bioelectron. 2016, 77, 76-82. [CrossRef]

14. Chan, C.M. An improved Synthesis of a Chemiluminescent Cyclic Hydrazide: N-(7-Aminobutyl)N-ethyl-naphthalene-1,2-dicarboxylic hydrazide. Synth. Commun. 1989, 19, 1981-1985. [CrossRef]

15. Ishida, J.; Yamaguchi, M.; Nakahara, T.; Nakamura, M. 4,5-Diaminophthalhy drazide as a highly Sensitive Chemiluminescence Reagent for $\alpha$-Keto Acids in Liquid Chromatography. Anal. Chim. Acta 1990, 231, 1-6. [CrossRef]

16. Sasamoto, K.; Ohkura, Y. A New Chemiluminogenic Substrate for $N$-Acetyl- $\beta$-D-glucosaminidase, 4'-(6'-Diethylaminobenzofuranyl)phthalylhydrazido-N-acetyl- $\beta$-D-glucosaminide. Chem. Pharm. Bull. 1991, 39, 411-416. [CrossRef]

17. Ishida, J.; Takada, M.; Yakabe, T.; Yamaguchi, M. Chemiluminescent Properties of some Luminol related Compounds. Dyes Pigm. 1995, 27, 1-7. [CrossRef]

18. Ishida, J.; Takada, M.; Hara, S.; Sasamoto, K.; Kina, K.; Yamaguchi, M. Development of a Novel Chemiluminescent Probe, 4-(5',6'-dimethoxybenzothiazolyl)phthalhydrazide. Anal. Chim. Acta 1995, 309, 211-219. [CrossRef]

19. Yoshida, H.; Nakao, R.; Nohta, H.; Yamaguchi, M. Chemiluminescent Properties of some Luminol-related compounds-Part 3. Dyes Pigm. 2000, 47, 239-245. [CrossRef]

20. Smith, M.B.; March, J. March's Advanced Organic Chemistry: Reactions, Mechanisms, and Structure, 6th ed.; John Wiley \& Sons: Hoboken, NJ, USA, 2007.

21. Antonov, L. Tautomerism: Methods and Theories, 1st ed.; Wiley-VCH: Weinheim, Germany, 2013.

22. Ali Ahmed, H.E.; Abdel-Salam, H.A.; Shaker, M.A. Synthesis, Characterization, Molecular Modeling, and Potential Antimicrobial and Anticancer Activities of Novel 2-Aminoisoindoline-1,3-dione derivatives. Bioorg. Chem. 2016, 66, 1-11. [CrossRef]

23. Conchon, E.; Anizon, F.; Aboab, B.; Golsteyn, R.M.; Léonce, S.; Pfeiffer, B.; Prudhomme, M. Synthesis, in Vitro Antiproliferative Activities, and Chk1 Inhibitory Properties of Pyrrolo[3,4-a]carbazole-1,3-diones, Pyrrolo[3,4-c]carbazole-1,3-diones, and 2-Aminopyridazino[3,4-a]pyrrolo[3,4-c]carbazole-1,3,4,7-tetraone. Eur. J. Med. Chem. 2008, 43, 282-292. [CrossRef]

24. Tseng, C.-C.; Yen, W.-P.; Tsai, A.-E.; Hu, Y.-T.; Takayama, H.; Kuo, Y.-H.; Wong, F.F. $\mathrm{ZnCl}_{2}$-Catalyzed Aza-Diels-Alder Reaction for the Synthesis of $1 H$-Pyrazolo[3,4- $b$ ]pyridine-4,5-dicarboxylate Derivatives. Eur. J. Org. Chem. 2018, 2018, 1567-1571.

25. Deshmukh, M.S.; Sekar, N. Chemiluminescence properties of luminol related quinoxaline analogs: Experimental and DFT based approach to photophysical properties. Dyes Pigm. 2015, 117, 49-60. [CrossRef]

26. Deshmukh, M.S.; Sekar, N. Chemiluminescence Properties of Luminol related $o$-Hydroxybenzimidazole analogues: Experimental and DFT based Approach to Photophysical Properties. Dyes Pigm. 2015, 113, 189-199. [CrossRef]

27. Peryasami, G.; Martelo, L.; Baleizã, C.; Berberan-Santos, M.N. Strong Green Chemiluminescence from Naphthalene analogues of Luminol. New J. Chem. 2014, 38, 2258-2261. [CrossRef]

28. Spurlin, S.R.; Cooper, M.M. A Chemiluminescent Precolumn Labelling Reagent for High-Performance Liquid Chromatography of Amino Acids. Anal. Lett. 1986, 19, 2277-2283. [CrossRef]

29. Yen, W.-P.; Liu, P.-L.; Uramaru, N.; Wong, F.F. Indium(III) chloride/silica gel catalyzed synthesis of pyrazolo[3,4-b]pyrrolo[3,4-d]pyridines. Tetrahedron 2015, 71, 8798-8803. [CrossRef]

30. Neumann, H.; Klaus, S.; Klawona, M.; Strúbina, D.; Húbner, S.; Gördes, D.; von Wangelin, A.J.; Lalk, M.; Beller, M. A New Efficient Synthesis of Substituted Luminols using Multicomponent Reactions. Z. Naturforsch. 2004, 59b, 431-438. [CrossRef] 
31. Flitsch, W.; Krämer, U.; Zimmerman, H. Cyclische Verbindungen mit Heterobrückenatomen, V. Zur Chemie der 1-Amino-pyrrole. Chem. Ber. 1969, 102, 3268-3276. [CrossRef]

32. Dey, S.K.; Lightner, D.A. 1,1'-Bipyrroles: Synthesis and Stereochemistry. J. Org. Chem. 2007, 72, 9395-9397. [CrossRef]

33. Gompper, R.; Sobotta, R. Neue Elektronenreiche Butadiene. Tetrahedron Lett. 1979, 11, 921-924. [CrossRef]

34. Fang, J.M.; Yang, C.C.; Wang, Y.W. Use of $\alpha$-Anilino Dienenitriles as Nucleophiles in Cycloadditions. J. Org. Chem. 1989, 54, 477-481. [CrossRef]

35. Tyagi, P.; Venkateswararao, A.; Thomas, K.R.J. Solution Processable Indoloquinoxaline derivatives containing Bulky Polyaromatic Hydrocarbons: Synthesis, Optical Spectra, and Electroluminescence. J. Org. Chem. 2011, 76, 4571-4581. [CrossRef]

36. Martelo, L.; Periyasami, G.; Fedorov, A.A.; Baleizão, C.; Berberan-Santos, M.N. Chemiluminescence of Naphthalene analogues of Luminol in Solution and Micellar Media. Dyes Pigm. 2019, 168, 341-346. [CrossRef]

37. Reichardt, C. Solvatochromic Dyes as Solvent Polarity Indicators. Chem. Rev. 1994, 94, 2319-2358. [CrossRef]

38. Dutkiewlcz, M. Classification of Organic Solvents based on Correlation between Dielectric $\beta$ Parameter and Empirical Solvent Polarity Parameter $\mathrm{E}^{\mathrm{N}} \mathrm{T}$. J. Chem. Soc. Faraday Trans. 1990, 86, 2237-2241. [CrossRef]

39. Behera, S.K.; Karak, A.; Krishnamoorthy, G. Photophysics of 2-(4'-Amino-2'-hydroxyphenyl)$1 H$-imidazo-[4,5-c]pyridine and its analogues: Intramolecular Proton Transfer Versus Intramolecular Charge Transfer. J. Phys. Chem. B 2015, 119, 2330-2344. [CrossRef] [PubMed]

40. Behera, S.K.; Murkherjee, A.; Sadhuragiri, G.; Elumalai, P.; Sathiyendiran, M.; Kumar, M.; Mandal, B.B.; Krishnamoorthy, G. Aggregation induced enhanced and Exclusively Highly Stokes Shifted Emission from an Excited State Intramolecular Proton Transfer Exhibiting Molecule. Faraday Discuss. 2017, 196, 71-90. [CrossRef]

41. Chen, Y.-T.; Wu, P.-J.; Peng, C.-Y.; Shen, J.-Y.; Tsai, C.-C.; Hu, W.-P.; Chou, P.-T. A study of the Competitive Multiple Hydrogen Bonding Effect and its associated Excited-state Proton Transfer Tautomerism. Phys. Chem. Chem. Phys. 2017, 19, 28641-28646. [CrossRef]

42. Wang, Q.; Niu, Y.; Wang, R.; Wu, H.; Zhang, Y. Acid-induced Shift of Intramolecular Hydrogen Bonding Responsible for Excited-state Intramolecular Proton Transfer. Chem. Asian J. 2018, 13, 1735-1743. [CrossRef]

43. Tang, Z.; Lu, M.; Liu, K.; Zhao, Y.; Qi, Y.; Wang, Y.; Zhang, P.; Zhou, P. Solvation Effect on the ESIPT Mechanism of 2-(4'-Amino-2'-hydroxyphenyl)-1H-imidazo-[4,5-c]pyridine. J. Photochem. Photobiol. A 2018, 367, 261-269. [CrossRef]

44. Satapathy, A.K.; Behera, S.K.; Yadav, A.; Laxmi Mahour, L.N.; Yelamaggad, C.V.; Sandhya, K.L.; Sahoo, B. Tuning the Fluorescence Behavior of Liquid Crystal Molecules containing Schiff-base: Effect of Solvent Polarity. J. Lumin. 2019, 210, 371-375. [CrossRef]

45. Skripnikova, T.A.; Lysova, S.S.; Zevatskii, Y.E.; Myznikov, L.V.; Vorona, S.V.; Artamonva, T.V. Physico-chemical Properties of Isomeric Forms of Luminol in Aqueous Solutions. J. Mol. Struct. 2018, 1154, 59-63. [CrossRef]

46. Deepa, S.; Reddy, S.R.; Rajendrakumar, K. Green Chemiluminescence of Highly Fluorescent Symmetrical Azo-based Luminol derivative. Orient. J. Chem. 2018, 34, 894-905. [CrossRef]

47. Brouwer, A.M. Standards for Photoluminescence Quantum Yield Measurements in Solution (IUPAC Technical Report). Pure Appl. Chem. 2011, 83, 2213-2228. [CrossRef]

48. Kiyama, M.; Iwano, S.; Otsuka, S.; Lu, S.W.; Obata, R.; Miyawaki, A.; Hirano, T.; Maki, S.A. Quantum Yield Improvement of Red-light-emitting Firefly Luciferin Analogues for in vivo Bioluminescence Imaging. Tetrahedron 2018, 74, 652-660. [CrossRef]

Sample Availability: Samples of the compounds are available from the authors. 